\author{
Marek MiŁawicki OP \\ (1D) https://orcid.org/0000-0001-9718-6216 \\ Dominikański Instytut Historyczny w Krakowie \\ Klasztor oo. Dominikanów we Wroceawiu
}

\title{
PRZYCZYNEK DO ORMIAŃSKO-POLSKIEGO RODOWODU AJWAZOWSKICH LIST ARCYBISKUPA GABRIELA AJWAZOWSKIEGO DO OJCA SADOKA BARĄCZA Z 1875 ROKU
}

\begin{abstract}
Abstrakt: W korespondencji o. Sadoka Barącza OP, historyka Ormian polskich, przechowywanej w Bibliotece Zakładu Narodowego im. Ossolińskich we Wrocławiu, znajduje się list od ormiańskiego arcybiskupa Gabriela Ajwazowskiego, brata malarza Iwana. Pośrednikiem w kontaktach obu uczonych był ziemianin ormiański z Galicji - Robert Bogdanowicz. List dotyczy rodzinnej tradycji Ajwazowskich na temat ich pochodzenia ze społeczności polskich Ormian z miasta Stanisławów. Choć list był już w literaturze przedmiotu wykorzystywany, nigdy nie został w pełni przeanalizowany. Artykuł zawiera edycję listu w oryginalnym języku francuskim i w tłumaczeniu na język polski oraz próbę weryfikacji zawartych w nim danych na podstawie metryk parafii ormiańskokatolickich w Galicji na tle życiorysu jej autora.

Słowa kluczowe: Gabriel Ajwazowski, Iwan Ajwazowski, Sadok Barącz, Ormianie polscy, Ormianie rosyjscy, mechitaryści, Galicja, Rosja, Kościół ormiański, wiek XIX
\end{abstract}

Gabriel Ajwazowski (1812-1879) i Sadok Barącz (1814-1892) to znani badacze dziejów, kultury, literatury i języka narodu ormiańskiego. Obaj wywodzili się z rodzin obrządku ormiańskokatolickiego i obaj byli duchownymi, przy czym pierwszy związał się z ormiańskim Kościołem narodowym, a drugi - z Kościołem rzymskokatolickim. Mieli też wspólnego znajomego, Roberta Bogdanowicza, z którym niezależnie od siebie korespondowali. Był to właściciel majątku 
ziemskiego w Litiatynie w powiecie brzeżańskim i prowizor parafii ormiańskokatolickiej w Brzeżanach, który żywo interesował się historią Ormian polskich i publikował na ten temat. To właśnie on przekazał Ajwazowskiemu, wówczas arcybiskupowi ormiańskiemu w Teodozji (dawnej Kaffie) na Krymie w Rosji, informacje o Barączu, dominikaninie w austriackiej Galicji, i jego badaniach nad dziejami nacji ormiańskiej na ziemiach polskich. Z jego też inicjatywy hierarcha napisał do zakonnika list w języku francuskim, datowany na 25 stycznia (6 lutego) 1875 roku. To liczące trzy strony źródło epistolarne stanowi przedmiot niniejszego artykułu.

List Ajwazowskiego znajduje się w zbiorze korespondencji Barącza, który tenże przekazał do lwowskiego Ossolineum, a który po drugiej wojnie światowej trafił do Zakładu Narodowego im. Ossolińskich we Wrocławiu ${ }^{1}$. Ostatnio drukiem ukazały się listy, które pomiędzy sobą pisali Barącz i August Bielowski, kustosz Ossolineum² ${ }^{2}$ Do osobnego wykorzystania posłużyły także listy kilku badaczy historii zakonu bazyliańskiego do Barącza ${ }^{3}$. Jednak należy podkreślić, iż większość korespondencji, którą zakonnik otrzymywał od różnych badaczy, literatów, redaktorów, wydawców, bibliotekarzy arystokratów i duchownych, nadal nie jest wprowadzona do obiegu naukowego, a tym bardziej nie doczekała się edycji, na którą z pewnością zasługuje ${ }^{4}$. Omawiany tutaj list arcybiskupa Ajwazowskiego był już wcześniej znany historykom. W 1970 roku o jego istnieniu informował ukraiński badacz Jarosław Daszkiewicz, jednak w żaden sposób go nie omówił ${ }^{5}$ W monografii o twórczości Barącza lakonicznie wspomniał o nim Rafajel Hambarcumian jako przykładzie jego kontaktów z przedstawicielami świata ormiańskiego ${ }^{6}$. To właśnie od Hambarcumiana kopię listu otrzymał

1 Biblioteka Zakładu Narodowego im. Ossolińskich we Wrocławiu (dalej: BZNiO): sygn. 2756, list arcybiskupa G. Ajwazowskiego do o. S. Barącza, Teodozja, 25 stycznia (6 lutego) 1875 roku.

2 M. Miławicki, ,Zostaje raz na zawsze życzliwym przyjacielem”. Korespondencja pomiędzy historykami Augustem Bielowskim i dominikaninem Sadokiem Barączem, „Galicja. Studia i Materiały", 3, 2017, s. 277-349.

${ }^{3}$ M. Miławicki, „Dlaczegożbym tedy nie miat pisać o bazylianach?”. O. Sadoka Baracza OP zainteresowania historia zakonu św. Bazylego, w: Pro bibliothecarum et bibliothecariorum bono. Księga jubileuszowa z okazji 70. urodzin profesor Marii Pidtypczak-Majerowicz, red. J. Czyrek, B. Górna, Wrocław 2016, seria: Z problemów bibliotek naukowych Wroctawia, 12, s. 195-213.

${ }^{4}$ Szerzej o Sadoku Barączu i jego korespondencji zob. M. Miławicki, „Świat ode mnie zawsze rzeczy nadzwyczajnych wymagat, a ponadto niestusznie”. O. Sadok Wincenty Baracz OP (1814-1892) w świetle źródet, „Lehahayer”, 2, 2013, s. 153-198.

5 Я. Р. Даш кев ич, Материаль по истории армянских колоний на Украине в библиотеках Кракова и Врощлава, „Вестник Архивов Армении”, 1970, 3, s. 175-186.

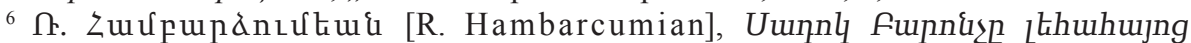
upuunúnıpłuiq nıunıúuuuhpnn [Sadok Barącz - badacz dziejów Ormian polskich], Epluui [Erywań] 1998, s. 28, 31. 
ormiański historyk Wardges Mikaelian i zacytował w swoim artykule jego fragment mówiący o przodkach i krewnych Gabriela i Iwana Ajwazowskich ${ }^{7}$. Za Mikaelianem fragment ten przywołują inni ich biografowie ${ }^{8}$. List wzmiankowany jest również we wstępie do wyboru dzieł Gabriela Ajwazowskiego, wydanych w języku ormiańskim w opracowaniu Szahena Chaczatriana ${ }^{9}$ Z polskich badaczy o liście wspomina Zbigniew T. Szmurło, powołując się na artykuł Mikaeliana $^{10}$, a ostatnio wykorzystał go Andrzej A. Zięba w artykule o Robercie Bogdanowiczu ${ }^{11}$.

Mimo tych kilku odwołań list Ajwazowskiego wart jest edycji i całościowej analizy. O jego wartości stanowi osoba samego autora, znanego w świecie ormiańskim z własnych wybitnych dokonań. Treść listu dotyczy też jego starszego brata Iwana, czyli Owanesa (1817-1900), który przeszedł do historii sztuki jako jeden z najsławniejszych malarzy rosyjskich XIX wieku. Obaj odegrali ważną rolę w dziejach Ormian w Rosji ${ }^{12}$. List świadczy też o autorytecie, jakim cieszył się Sadok Barącz. Wreszcie dokument ten mówi o roli, jaką w nawiązaniu relacji między polskimi Ormianami a Armenią odegrał Robert Bogdanowicz.

Sadok Barącz i Gabriel Ajwazowski są już dobrze znani w literaturze naukowej, przy czym biografia drugiego z nich, kilkakrotnie badana w historiografii ormiańskiej i rosyjskiej ${ }^{13}$, z rzadka była omawiana w ukraiń-

7 В. А. Микаелян, И. К. Айвазовский и его соотечественники, „Lpuptp Zuuupuquiluuq 9punnıpjnı\{quph" [Biuletyn Nauk Społecznych], 1991, 1, s. 69-70.

${ }^{8}$ Zob. np. Е. А. Скоробогачева, Айвазовский, Москва 2021, seria: Жизнь замечательных людей, s. 8-9.

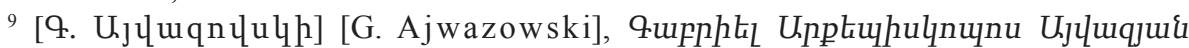
(Uıluqnцulh). 1812-1879. Equnpuih [Gabriel arcybiskup Ajwazjan (Ajwazowski). 18121879. Wybór], oprac. T. Kuu ¿uunpjư [Sz. Chaczatrian], Epluuiq [Erywań] 2012.

10 Z. T. Szmurło, Gabriel Ajwazowski - duchowny, uczony i pedagog, ,Kognitywistyka i Media w Edukacji”, 2013, 2, s. 159.

11 A. A. Zięba, Idea powrotu Ormian z rozproszenia do narodowej ojczyzny w świetle memoriałów Roberta Bogdanowicza z 1877 i 1884 roku, „Lehahayer”, 7, 2020, s. 201-202.

12 В. А. Микаелян, На Крымской земле. История армянских поселений в Крыму, Ереван 1974; Ш. Хачатрян, Братья Айвазовськие, „Третьяковская галерея”, 2016, 4 (53), s. 148-161; A. Ferrari, I fratelli Ayvazean. Ajvazovskij tra la Crimea e Venezia, „Annuario dell'Instituto Romeno di Cultura e Ricerca Umanistica di Venezia”, 14-15, 2012-2013, s. 185-195.

13 Poza pozycjami przywołanymi w innych przypisach zob. Г. Карауло в, Гавриил Айвазовский, архиепископ армяно-григорианский, „Записки Імператорского одесского общества истории и древностей”, 12, 1881, s. 435-443; Айвазовскій Гавріиль Константиновичъ, w: Русскій біографическій словарь, 1, С.-Петербургъ 1896, s. 87-88; В. Микаелян, Армянская Энциклопедия. Габриел Айвазовский (Айвазян), „Голубь Масиса”, 1997, 12, s. 3; 13, s. 3; 14, s. 3, 6; С. Гарибджанян, Деятели армянской Церкви (XIX-XX вв.). Биографические очерки, Ереван 2005, s. 79; Д. Дав тян, Неизвестные страницы жизни архимандрита Гавриила Айвазовского (Габриеля Айвазяна), „Исследования по арменистике в Украине", 1, 2008, s. 106-111; Ю. В. Захаро ва, Религиозная и просветительская 
skiej $^{14}$, włoskiej ${ }^{15} \mathrm{i}$ francuskiej ${ }^{16}$, a prawie w ogóle w polskiej ${ }^{17}$. Dlatego też jemu trzeba tu poświęcić nieco uwagi.

Autor omawianego listu przyszedł na świat 10 (22) maja 1812 roku w Teodozji, w ormiańskiej rodzinie kupieckiej. Jego ojcem był Kajetan Ajwas (Hajwas) ${ }^{18}$, który urodził się w Stanisławowie w roku 1765 lub $1766^{19}$ - a więc wywodził się z polskich Ormian oraz nosił typowe wśród nich imię katolickiego świętego - i w wyniku konfliktu z rodzeństwem przeniósł się do Mołdawii, gdzie przez pewien czas zajmował się handlem. Być może było to w tej części owego kraju, który w 1812 roku zajęła Rosja, czyli w Besarabii ${ }^{20}$, gdyż na początku XIX stulecia Kajetan Ajwas był już poddanym rosyjskim. Ostatecznie osiadł w Teodozji. Prawdopodobnie wówczas przyjął imię Konstanty, którego używał do końca życia. Znał wiele języków obcych, z racji miejsca urodzenia i przynależności etnicznej - polski i ormiański, a także rosyjski, turecki, węgierski, niemiecki, podobno nawet jidysz i mowę Cyganów, a więc prawie wszystkie używane w tym regionie Europy, co pozwoliło mu zostać naczelnikiem bazaru. Zachował macierzysty obrządek ormiańskokatolicki, ale ożenił się z Rypsymą (1784-1860), która należała do ormiańskiego Kościoła narodowego. Mieszkali w domu położonym na skraju Teodozji, na wzniesieniu, z którego było widać panoramę miasta

деятельность Габриэла (Гавриила) Константиновича Айвазовского, „Причерноморье. История, политика, культура", seria: Б, 1, 2009, s. 175-178; С. С. Казаров, Айвазовский, Гавриил Константинович (1812-80), w: Армяне Причерноморья: энциклопедия, red. И. В. Кузнецов, 1, Москва 2020, s. 208-209.

14 О. І. Божко, Діяльність Габрієла Айвазовського в контексті суспільних процесів середини XIX cm., „Східний світ”, 2012, 4, s. 5-14; I. Гаюк, Ілюстрована енциклопедія вірменської культури в Україні: з каталогізованим додатком переліку пам'яток вірменської культури в музеях та заповідниках, 1, Львів 2012, s. 97-101, 200.

15 S. Haroutyunian, P. Gabriēl Ayvazean. L'editore e il traduttore, w: La Crimea tra Russia, Italia e Impero ottomano, red. A. Ferrari, E. Pupulin, Venezia 2017, seria: Eurasiatica, 8, s. 53-68.

16 F. Tournebize, Aïvazovsguy ou Ä̈vazovski (Gabriel), w: Dictionnaire d'histoire et de géographie ecclésiastiques, 1, red. A. Baudrillart et al., Paris 1912, s. 1234-1235.

17 Poza wspomnianym już popularyzatorskim artykułem Z. T. Szmurły, nie udało mi się znaleźć innych publikacji polskich mu poświęconych, a jedynie niewielkie hasła biograficzne w wydawnictwach leksykograficznych, np. A. Szafrański, Ajwazowski Gabriel, w: Encyklopedia katolicka, 1, Lublin 1973, kol. 206.

18 Pod takim nazwiskiem odnotowany został w księdze metrykalnej ormiańskiego kościoła św. Sarkisa w Teodozji przy chrzcie syna Owanesa (Iwana) w 1817 roku (Айвазовский. Документы и материаль, орrac. М. С. Саргсян, Г. Г. Арутюнян, Г. М. Шатирян, red. 3. Г. Башинджагяна, Ереван 1967, s. 9, dok. 1). Oryginał księgi znajduje się w Archiwum Narodowym Armenii (Zujuuunu\{h uqqujh\{ uphuһl) w Erywaniu: ф. 320, on. 1 д. 78.

19 Tak według Gabriela Ajwazowskiego. W niektórych opracowaniach podawany jest rok 1771, ale bez powołania się na jakąkolwiek podstawę źródłową.

${ }^{20}$ Migracja Ormian polskich z Galicji do Besarabii była w tym czasie zjawiskiem znaczącym. Zob. o tym: J. Ber, Ormianie polscy w Besarabii, „Lehahayer”, 4, 2017, s. 99-147. 
i portu ${ }^{21}$. Małżeństwo Haywazowskich - jak się jeszcze wówczas nazywali doczekało się pięciorga dzieci, które wszystkie zostały ochrzczone w obrządku matki ${ }^{22}$. Starszy o cztery lata brat Gabriela, Grigorij (1808-1881), całe swoje życie związał $\mathrm{z}$ rodzinnym miastem, pracując $\mathrm{w}$ nim jako kapitan portu kwarantannego. Teodozja była ważnym punktem handlu czarnomorskiego i w jej porcie sprawdzano załogi i ładunki statków przybywających z różnych krajów pod względem ewentualnych epidemii. Grigorij doczekał się nominacji na radcę tytularnego, a w 1853 roku - asesora kolegialnego ${ }^{23}$. O pięć lat młodszym od Gabriela Owanesie, znanym bardziej pod rosyjskim imieniem Iwan, wspomniałem już wyżej. Jest on najsłynniejszym przedstawicielem tej rodziny, jako jeden z najwybitniejszych malarzy rosyjskich i ormiańskich żyjących w XIX wieku². Były jeszcze dwie siostry: Elena i Katarzyna. Druga z nich wyszła za ormiańskiego kupca Grigorija Mazirowa (Mazirianca), z którym miała dwóch synów: Demosfena (Demostenesa) (1839-1905) i Lewona (Leonida) (ur. ok. 1840). Pierwszy

${ }^{21}$ W 1881 roku ulica, na której znajdował się dom rodzinny Ajwazowskich, została nazwana imieniem ich syna Iwana, który wówczas otrzymał również honorowe obywatelstwo miasta za swoje osiągnięcia artystyczne i ,zasługi oddane miastu”. Por. Айвазовский. Документы и материаль, s. 180-181, dok. 144. Szerzej zob. М. А. Араджиони, Формирование армянских общин в восточном Крыму (конец XVIII - первая половина XIX веков), „Исследования по арменистике в Украине”, 1, 2008, s. 79-93.

${ }^{22}$ Szerzej o rodzinie Ajwazowskich zob. М. Багдасарян, Семья Айвазовских в Феодосии, [b.m.w.] 2019. Większa część tego popularnego opracowania poświęcona jest rodzinie Iwana Ajwazowskiego, tam też znajdują się zdjęcia i reprodukcje obrazów malarza, przedstawiające członków rodziny, w tym rodziców i brata Gabriela.

${ }^{23}$ І. Гаюк, Айвазовский, Григорий Константинович (1801-1881), w: Армяне Причерноморья, s. 209. W opracowaniach na temat rodziny Ajwazowskich, w większości poświęconych malarzowi Iwanowi, nie znajdujemy jednolitego przekazu na temat jego rodzeństwa. W wielu z nich Grigor w ogóle nie jest wspominany, innym razem mowa jest, że najstarszym bratem Iwana był Gabriel. Brak jest obecnie możliwości dotarcia do ksiąg metrykalnych, co nie pozwala na weryfikację tych sprzecznych danych. Miejsce przyjęcia chrztu przez dzieci Ajwazowskich także nie jest pewne, i tutaj mamy chaos informacyjny.

24 Por. И. Гинзбург, Армянские художники первой половины ХІХ в., „Тuunưupuquuhpulqui huqntu" [Czasopismo Historyczno-Filologiczne], 1958, 3, s. 125; И. Я. Семенов, Русские в истории Армении, red. М. Д. Амирханян, Ереван 2009, s. 104-105. Szerzej o samym malarzu zob. nр. П. П. Каратыгин, Иванъ Константиновичъ Айвазовскій и его ХLII-хъ льтняя художественная дъяттельность 1836-1878, „Русская старина", 9, 1878, 21, s. 649-674; 22, s. 423-444; 23, s. 55-74, 281-306; 1881, 31, s. 411-436; Л. Е. Мазиров, Иван Константинович Айвазовский. По поводу его пятидесятилетнего юбилея, сборник статей из «Правительственного вестника», Санкт-

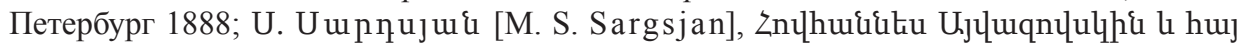

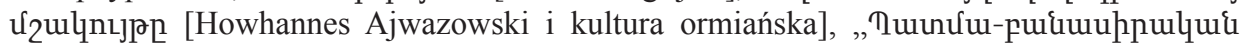
huuntuu" [Czasopismo Historyczno-Filologiczne], 1963, 4, s. 25-38; Н. С. Барс а м о в, Иван Константинович Айвазовский. 1817-1900, Москва 1962; Л. А. Вагнер, Н. С. Григорович, Айвазовский, Москва 1970; A. Ter-Minassian, Ä̈vazovski (1817-1900), un peintre Armenien dans le grand siecle Russe, „Fuquuultux / Bazmavep”, 167, 2009, s. 486-515. 
był architektem i pozostawił po sobie wiele budowli, szczególnie w Odessie, gdzie też ożenił się z Ormianką, córką kupca Jemeliana Murzajewa - Marianną, przynależną do wyznania ormiańskokatolickiego ${ }^{25}$. Natomiast Lewon Mazirow był krytykiem sztuki. W latach 1853-1857 pracował w Muzeum Starożytności w Kerczu na Krymie. W 1853 i 1856 roku brał udział w wykopaliskach archeologicznych, które organizował jego wuj Iwan Ajwazowski ${ }^{26}$, był też organizatorem jego wystaw i jednym z pierwszych biografów ${ }^{27}$. Interesujące jest dla nas to, że był autorem artykułu o diasporze ormiańskiej na ziemiach polskich ${ }^{28}$ - dowodu zainteresowań przeszłością rodzinną - napisanego w 1889 roku po podróży na Podole, oczywiście wtedy już rosyjskie. Opisał w nim ocalałe zabytki, m.in. w Kamieńcu Podolskim, Żwańcu i Mohylewie Podolskim, zaczerpnięte ze źródeł historycznych informacje uzupełnił o własne spostrzeżenia i już w samym tytule podkreślił historyczną przynależność tej diaspory do Polski, nie usiłując odnieść jej ani do Rosji, ani do Ukrainy.

Wróćmy jednak do Gabriela Ajwazowskiego. Chrzest w wierze ormiańskiej otrzymał prawdopodobnie w cerkwi św. Grzegorza ${ }^{29}$ wraz z imieniem Aleksander. Uczył się w ormiańskiej szkole parafialnej w rodzinnej miejscowości, a potem w Karasubazarze (obecnie: Biełogorsk) u mechitarysty Minasa Bżyszkianca ${ }^{30}$, duszpasterza Ormian katolików na Krymie ${ }^{31}$. Uzdolnionego chłopca duchowny ten wysłał na dalszą edukację do klasztoru swojej kongregacji zakonnej na

25 Szerzej o Demosfenie Mazirowie zob. Д. А. Давтян, Творчество армянского архитектора Демосфена Григорьевича Мазирова в Одессе, „Воронцовский сборник”, 4, 2011, s. 21-29.

${ }^{26}$ С. В. Полин, А. Ю. Алексеев, Скифский ияарский Александропольский курган IV в. до н. э. в Нижнем Поднепровье, Киев-Берлин 2018, seria: Курганы Украины,, 6, s. 31, 77-78, 81, 140, 142.

27 Л. Е. Мазиров, Иван Константинович Айвазовский.

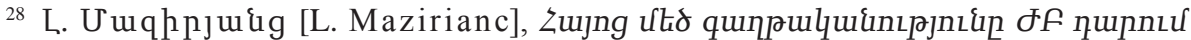

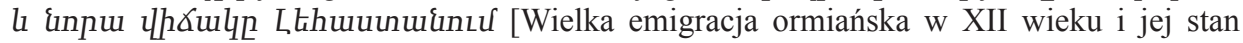
w Polsce], „Unupu” [Araks], 1889, 1, nr 7, s. 126-136. O wartości tej pracy świadczy to, że wielokrotnie cytuje ją Wartam Grigorian, współczesny badacz dziejów Ormian na Podolu [В. Р. Григорян, История армянских колоний Украины и Польши (Армяне в Подолии), Ереван 1980], nie podając jednak, że Mazirianc to siostrzeniec Ajwazowskich. Za zwrócenie uwagi na pokrewieństwo Lewona Mazirianca z Ajwazowskimi dziękuję Andrzejowi A. Ziębie.

29 Por. Г. Караулов, Гавриил Айвазовский, архиепископ армяно-григорианский, s. 436. W biografiach Gabriela Ajwazowskiego jako miejsce chrztu podawane są różne świątynie: czasami jest to kościół św. Grzegorza, innym razem wspomina się kościół św. Sarkisa.

30 А. Д. Тимиргазин, Член армяно-католической Конгрегации Мхитаристов на острове Св. Лазаря в Венеиии Минас Бжшкяни (Минас Медици), „Исследования по арменистике в Украине”, 1, 2008, s. 112-116; T. Sargsjan, Minas Bżyszkian i jego relacja o Ormianach Lwowa, „Lehahayer”, 5, 2019, s. 159-193.

31 Л. В. Арутюнян, Католики-армяне в Крыму и их вклад в мировую культуру, „Причерноморье. История, политика, культура”, 2012, 9, s. 12. 
wyspie San Lazzaro w Wenecji ${ }^{32}$. Miał duży wpływ na młodego wówczas Aleksandra, który później, podobnie jak on, zajął się pracą naukową. Naukę u mechitarystów weneckich chłopiec pobierał w latach 1826-1830, a po jej ukończeniu wstąpił do ich zakonu. Podczas obłóczyn przyjął imię Gabriel, pod którym później występował ${ }^{33}$. W Wenecji odbył formację zakonną i dalsze studia teologiczne. W 1834 roku otrzymał stopień wardapeta (odpowiednik stopnia doktorskiego), a wraz z nim zaszczytny pastorał w kształcie laski zakończonej krzyżem i głowami dwóch węży, symbolizujący wiedzę i władzę nauczania. Znał wiele języków: nowoormiański, hebrajski, grekę, łacinę, arabski, nowoperski, włoski, francuski, rosyjski, niemiecki i angielski, jednak pracował głównie w staroormiańskim grabarze. W prowadzonej przez klasztor szkole wykładał teologię, filozofię oraz języki wschodnie i europejskie. To właśnie on był mentorem jednego z najwybitniejszych historyków i poetów ormiańskich w XIX wieku Ghewonda Aliszana. W okresie weneckim Ajwazowski napisał dwie prace w języku ormiańskim: Zarys historii Rosji (1835) 34 i dwutomową Historię imperium otomańskiego (1841) ${ }^{35}$. Współpracował również ze swoim współbratem zakonnym Howannesem Mygerdiczem Awgerianem (Jeanem-Baptistem Aucherem) przy tworzeniu słownika ormiańskiego, który do dnia dzisiejszego jest pomnikiem ormiańskiej filologii narodowej ${ }^{36}$. Wtedy też dokonał kilku przekładów autorów ormiańskich na języki europejskie. W latach 1843-1848 redagował założone przez siebie czasopismo historyczno-filologiczne „Fuquuultıu / Bazmavep”, w którym publikował studia naukowe i teksty beletrystyczne oraz thumaczenia na język ormiański ${ }^{37}$. Czasopismo to szybko zdobyło poważanie i jest wydawane do chwili obecnej.

32 Szerzej o wspólnocie mechitarystów weneckich zob. San Lazzaro degli Armeni. L'isola, il monastero, il restauro, red. M. Maguolo, M. Bandiera, Venezia 1999; Gli Armeni e Venezia. Dagli Sceriman a Mechitar. Il momento culminante di una consuetudine millenaria, red. B. L. Zekiyan, A. Ferrari, Venezia 2004. Kongregacji mechitarystów w Wenecji poświęcony jest cały numer wydawanego przez nich w języku ormiańskim czasopisma „Fuquuultıu / Bazmavep” (2017, 3-4).

${ }^{33}$ O Gabrielu Ajwazowskim - mechitaryście zob. 3. Tphgł uq [H. Iricjan], qupphŁL

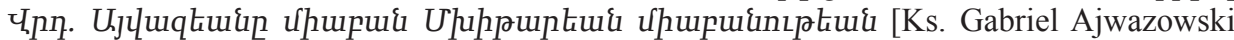
jako członek Kongregacji Mechitarystów], „Fuquulltuw / Bazmavep”, 2017, 3-4, s. 140-162.

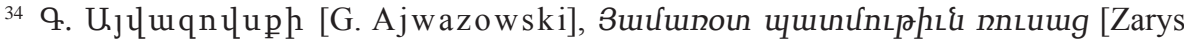
historii Rosji], પ,tutiunhl [Wenecja] 1836.

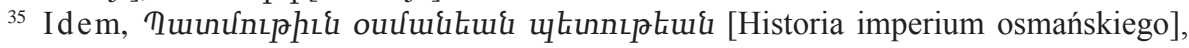
1-2, પ.tiliunhl [Wenecja] 1841.

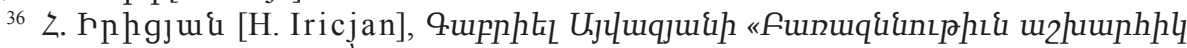

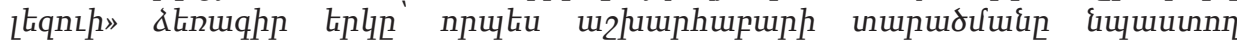
ůhuuunnıpjnı\{ [Rękopis Gabriela Ajwazowskiego „Analiza słów języka świeckiego” jako dzieło promujące rozpowszechnianie się współczesnego języka ormiańskiego], „Fuupłp Uuuntiuunupuith" [Biuletyn Matenadaranu], 27, 2019, s. 371-387.

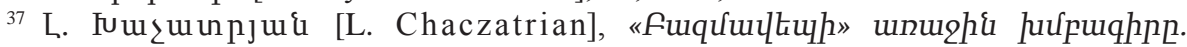

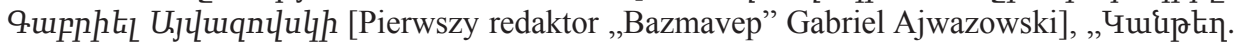


W 1848 roku Ajwazowski przeniósł się do Paryża, gdzie przez siedem lat był dyrektorem liceum Samuela Muradiana (Mourata, Moorata) - Unıpuiฑjuiq цuupdupuí. Placówka ta, przeniesiona z Padwy, stała się ważnym ośrodkiem odrodzenia Ormian we Francji, do której przybywało wielu młodych Ormian z imperium osmańskiego ${ }^{38}$. Do szkoły uczęszczali nie tylko chłopcy ormiańskokatoliccy, ale także wyznania narodowego, co wzbudzało dezaprobatę Stolicy Apostolskiej, której jurysdykcji szkoła podlegała. Rodziło to napięcia między o. Ajwazowskim a kongregacją mechitarystów ${ }^{39}$ i wreszcie w 1855 roku opuścił on zakon, porzucił katolicyzm i przeszedł do ormiańskiego Kościoła narodowego, do czego już od lat namawiał go brat Iwan ${ }^{40}$. Razem z o. Gabrielem konwersji dokonało jeszcze kilku innych mechitarystów: Sarkis Teodorian oraz bracia Ambrosios i Choren Galfajanowie ${ }^{41}$. Dwaj pierwsi razem z Ajwazowskim wydali broszurę, w której wyjaśniali motywy swojej decyzji ${ }^{42}$. W Grenelle pod Paryżem

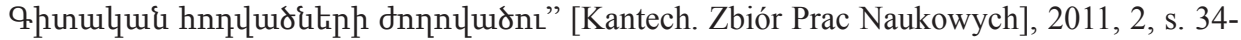

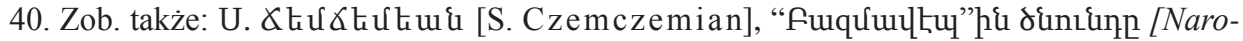
dziny „Bazmavep”], „,Fuquuultu / Bazmevep”, 150, 1994, s. 49-66.

38 Szerzej o edukacji młodzieży ormiańskiej we Francji zob. J. Mathorez, Les Arméniens en France: de 1789 à nos jours, „Revue Études Arméniennes”, 2, 1922, s. 293-314; J. Etmekjian, The French Influence on the Western Armenian Renaissance 1843-1915, New York 1964; A. Şişman, Egyptian and Armenian Schools Attended by Ottoman Students in Paris, „Uşak Üniversitesi Sosyal Bilimler Dergisi”, 2009, 2, s. 1-10; C. Mouradian, A. Kunth, Les Arméniens en France. Du chaos à la reconnaissance, Toulouse 2010; A. Kirmizi, European Educational Backgrounds of Armenian Officials in the Ottoman Empire, w: Middle Eastern Christians and Europe: Historical Legacies and Present Challenges, red. A. Schmoller, Zürich 2018, seria: Orientalia - Patristica - Oecumenia, 13, s. 59-77.

39 J. Mathorez, Les Arméniens en France, s. 299.

40 Айвазовский. Документы и материаль,, s. 124-125, dok. 93; В. А. Микаелян, И. К. Айвазовский и его соотечественники, s. 61. Wkład w konwersję o. Gabriela Ajwazowskiego miał też Instytut Języków Wschodnich im. Łazariewa w Moskwie, z którym utrzymywał kontakty naukowe i skąd dostarczano mu materiały negatywnie naświetlające Kościół ormiańskokatolicki. W 1858 roku, już po konwersji, obaj bracia Ajwazowscy odwiedzili Instytut [В. Р. Аветисян, Институт восточных языков (Лазаревский Институт) как иентр русско-армянских взаимоотночений в XIX-первой четверти XX вв., Ставрополь 2018, s. 150, praca doktorska dostępna w wersji elektronicznej: https://www.ncfu.ru/science/ dissertacionnye-sovety/obyavleniya-o-zaschite-dissertaciy/avetisyan-vladimir-rudol_fovich/ index.html].

${ }^{41}$ The heritage of Armenian literature, 3, From the eighteenth century to modern times, red. A. J. Haciky an et al., Detroit 2000, s. 336-338. Choren Galfajan współpracował z Ajwazowskim również $\mathrm{w}$ okresie krymskim, ucząc w założonej przez niego szkole chalibowskiej.

${ }^{42}$ U. otnnnptiuq [S. Teodorian], 9. Ujuuqtuuq [G. Ajwazowski],

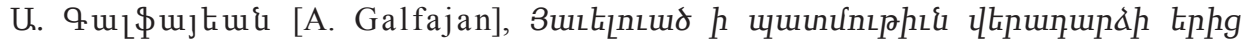

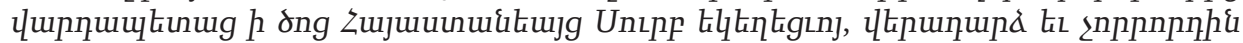

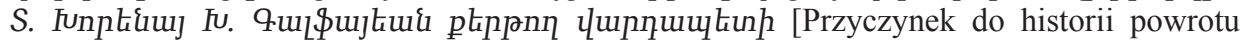
trzech wardapetów do Świętego Kościoła Ormiańskiego, powrót i czwartego T[er] Chorena Ch. Galfajana], Фuuph [Paryż] 1858. 
założyli konkurencyjne Kolegium Hajgasjana (Collège Haygasian), w którym nauczali młodzież ormiańską. Ajwazowski ponadto rozpoczął wydawanie czasopisma pt. „Uuuukurg unuulup” / „La Colombe du Massis” w języku ormiańskim i francuskim ${ }^{43}$.

W 1857 roku katolikos Nerses V (1770-1857) mianował Gabriela Ajwazowskiego biskupem diecezji besarabsko-nachiczewańskiej ${ }^{44}$, jednak z powodu śmierci katolikosa święcenia biskupie zostały odłożone. Z listów Iwana Ajwazowskiego do Christofora Łazariewa, pracującego wtedy w rosyjskim Ministerstwie Spraw Zagranicznych, dowiadujemy się, że jego brat był kandydatem na katolikosa ${ }^{45}$. Ostatecznie na urząd ten został wybrany Mateos I Czuchadżjan ${ }^{46}$, z którym później Ajwazowski popadł w konflikt. Do Teodozji Gabriel Ajwazowski przybył w czerwcu 1857 roku i od razu objął obowiązki administratora diecezji, przenosząc jej kurię i konsystorz z Kiszyniowa do rodzinnego miasta. Był najwybitniejszym rządcą tej diecezji ${ }^{47}$. To dzięki jego inicjatywie

${ }^{43}$ C. Mouradian, La vitalité d'une presse en diaspora, w: Presse et mémoire. France des étrangers, France des libertés, Paris 1990, s. 37; K. Beledian, Cinquante ans de littérature arménienne en France. Du même à l'autre, Paris 200, s. 26; C. Mouradian, A. Kunth, Les Arméniens en France, s. 13.

${ }^{44}$ Była ona jedną z sześciu diecezji Kościoła ormiańskiego w imperium rosyjskim. Por. В. Блохин, Этапь и содержание армяно-русского межконфессионального диалога: исторический и современный опыт, „Fuiptep Epluwih hưưuupuih" [Biuletyn Uniwersytetu Erywańskiego], seria: Uhquqqujh\& hupupknnıpjnı\&quln, Puqupuqhunnıpjnı\{ [Stosunki Międzynarodowe i Nauki Polityczne], 2019, 1, s. 29. Szerzej o Kościele ormiańskim w Rosji zob. В. Г. Тунян, „Положение” Армянской иеркви 1836-1875, Ереван 2001. O Ormianach w Rosji w XIX wieku zob. A. Ferrari, Alla frontiera dell'Impero. Gli armeni in Russia (1801-1917), Milano 2000.

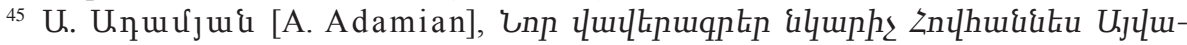
qnџulnı Uuuhq [Nowe dokumenty o artyście Iwanie Ajwazowskim], „ZUUR qu Stiptluqhp huuupulqulqui qhunnıpjnıkitph" [Biuletyn Nauk Społecznych Akademii Nauk ASRR], 1958, 11, s. 91-93.

${ }^{46}$ G. A. Bournoutian, Russia and the Armenians of Transcaucasia 1797-1889, Costa Mesa 1998, s. 418-419.

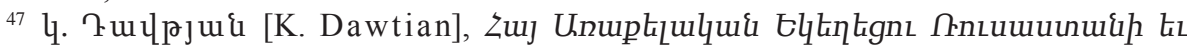

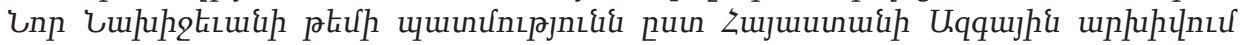

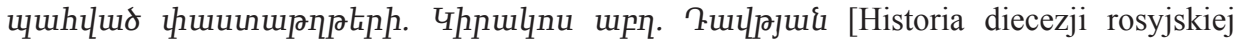
i nowo-nachiczewańskiej Ormiańskiego Kościoła Apostolskiego według dokumentów z Naro-

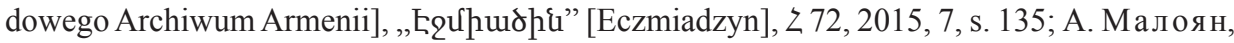
Очерк о духовно-просветительской деятельности ново-нахичеванской и бессарабской епархии (1830-1918), w: 300 лет российской и ново-нахичеванской епархии Армянской Апостольской Церкви. Исторический путь и современность. Материаль Международной научной конференции (Москва, 24-25 октября 2017 г.), red. Б. Зулум я н, Москва 2018, s. 332. Na temat diecezji nachiczewańsko-besarabskiej zob. В. Г. Вартанян, С. С. Казаров, История Армянской Апостольской иеркви на Дону (XVIII-XX в.в.), Ростов-на-Дону 2004;

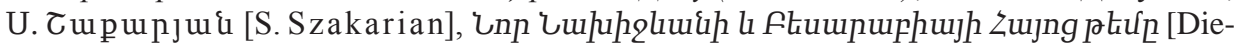
cezja ormiańska Nowego Nachiczewanu i Besarabii], Łquhurłh\{ [Eczmiadzyn] 2014. 
i współpracy z władzami rosyjskimi już w następnym roku powstała w Teodozji ormiańska szkoła, która od darczyńcy - Arutiuna Chalibiana (Chalibowa), kupca i burmistrza Nowego Nachiczewanu nad Donem ${ }^{48}$ - nazywana była ,szkołą chalibowską" ${ }^{49}$. Wyróżniała się organizacją i poziomem nauczania. O jej założeniu Ajwazowski myślał już w Paryżu, gdzie rozmawiał na ten temat $\mathrm{z}$ ambasadorem rosyjskim, hrabią Pawłem Kisielewem. Władze carskie poprzez tę szkołę chciały wpływać na Ormian w ogóle, a przede wszystkim na tych, którzy mieszkali w imperium osmańskim. Kształcili się w niej bowiem synowie wpływowych Ormian tureckich. Działała do 1871 roku, kiedy to została zamknięta z powodu braku funduszy. Ajwazowski dysponował też w Teodozji drukarnią, w której do 1865 roku kontynuował wydawanie swego czasopisma (pod zmienionym tytułem „Uıtinupkn Zujuuunuitluujg”), teraz nie tylko po ormiańsku i francusku, ale także po rosyjsku. Zamieszczał w nim informacje z życia diecezji, lokalnej wspólnoty ormiańskiej i szkoły, a także notatki z podróży, teksty literackie i artykuły o zabytkach ormiańskich ${ }^{50}$. Nadal zajmował się pracą naukową i translatorską. Przełożył na język ormiański bajki Iwana Kryłowa ${ }^{51}$, ponadto tłumaczył prace rosyjskich, włoskich, niemieckich i francuskich naukowców. Sam napisał

48 М. Г. Багдыков, Т. М. Багдыков, Арутюн Халибян, Ростов-на-Дону 2011.

49 Е. В. Барашьян, Исторический взгляд на судьбу халибовского армянского училищз в Феодосии, „Исследования по арменистике в Украине”, 2, 2010, s. 36-40; В. Г. Вартанян, Архиепископ Г. Айвазовский и основание Халибовского училища в Феодосии, w: Армяне юга России. История, культура, общее будущее. Материаль всероссийской научной конференции 30 мая - 2 июня 2012 г. Ростов-на-Дону, Ростов-на-Дону 2012, s. 334-340.

50 В. А. Микаелян, На крымской земле, s. 196-209; В. Григорьянц, Из истории армянской школь в Крыму, „Сурбхач”, 1998, 12, s. 5-8; idem, Вірмени Криму: минуле і сьогодення (Проблеми соціокультурного та етпополітпчного розвитку), Сімферополь 2005, sегіа: Серія додатків до паукового журналу „Кримський Архів”, s. 33-34; А. Тер-Саркисянц, Из истории формирования армянской диаспоры в России (X-XX вв), „Iran and the Caucasus”, 3/4, 1999/2000, s. 329; А. Малоян, Очерк о духовно-просветительской деятельности, s. 338; Т. Шушара, Становление и развитие образования ар-

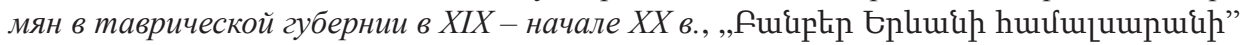
[Biuletyn Uniwersytetu Erywańskiego], seria: Zujuqqhunnıpjnı\{ [Armenistyka], 132, 2010, 1, s. 74-77; eadem, Развитие образования армян в Крыму ХІХ - начала ХХ века, „Гуманитарные науки”, 2015, 3 (31), s. 76-79; О. В. Волобуев, Армяне в Крыму: основные вехи истории, w: Армяне в истории и культуре России ХVIII-ХХ вв.: материаль международной научной конференции (Москва-Пушкино, 26-28 октября 2016 г.), red. П. М. Петров, Т. И. Любина, Ростов-на-Дону 2016, s. 202; А. Е. Тер-Саркисянц, Культурное наследие армян в Крыму, w: Армяне юга России, s. 195. Zob. również rozprawę doktorską: О. В. Моцовкіна, Развитие конфессиональных учебных заведений Крыма в ХX - первой половине ХХ века, Ялта 2011, s. 137-139 (http://dspace.pdpu.edu.ua/ handle/123456789/1133).

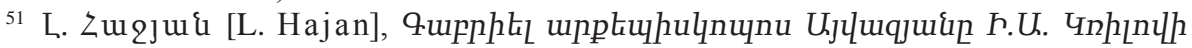
unulitiph punquuihs [Arcybiskup Gabriel Ajwazjan, thumacz bajek Kryłowa], Еqưurbi [Eczmiadzyn] 1976. 
zwięzłą gramatykę języka rosyjskiego i szczegółową gramatykę języka ormiańskiego, ale także szkice historyczne dotyczące zakonu mechitarystów ${ }^{52}$, unii kościelnej Ormian polskich (praca o bardzo antykatolickim wydźwięku) ${ }^{53}$, szkoły chalibowskiej ${ }^{54}$ i diaspory ormiańskiej w Rosji ${ }^{55}$.

Niechęć do Gabriela Ajwazowskiego ze strony katolikosa Mateosa I pogłębiało poparcie rządu carskiego dla niego i jego katolicka przeszłość. Katolikos zlecił nawet kontrolę w jego diecezji w 1862 roku. Choć starania o wybranie Ajwazowskiego na katolikosa eczmiadzyńskiego, podejmowane przez brata i czynniki rządowe, nie przyniosły rezultatów, kolejny katolikos, Geworg IV Kerestedżian, wybrany w 1866 roku, skończył z jego szykanowaniem. W 1867 roku otrzymał święcenia biskupie, a w 1871 roku został podniesiony do rangi arcybiskupa. 10 czerwca 1875 roku na zaproszenie katolikosa objął stanowisko inspektora (rektora) seminarium teologicznego w Eczmiadzynie ${ }^{56}$. W 1876 roku został zwierzchnikiem diecezji gruzińsko-imeretyńskiej z siedzibą w Tbilisi. Tam też zmarł 20 kwietnia 1880 roku i został pochowany na cmentarzu klasztornym. W 1977 roku jego ciało zostało przeniesione na plac przy kościele Sub Geworg ${ }^{57}$.

List arcybiskupa Gabriela Ajwazowskiego, będący przedmiotem moich rozważań, został napisany przed objęciem przez niego diecezji gruzińsko-imeretyńskiej. Poprzedziła go wcześniejsza znajomość Ajwazowskiego i Bogdanowicza, jeszcze z czasów, gdy pierwszy z nich działał w Paryżu. Znajomość ta, może nawet przyjaźń, a na pewno wspólne zainteresowanie sprawą ormiańską, trwała przynajmniej 18 lat, a więc od 1857 roku. Ajwazowski nie podaje wyraźnie, od kiedy znał się z Bogdanowiczem, jedynie wspomina, że właśnie wtedy otrzymał

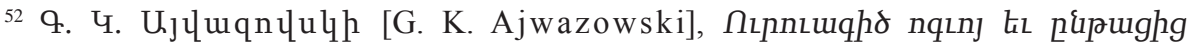
Uhuppuptiui uhupuinıpłuid [Zarys ducha i historii kongregacji mechitartystów], م Łnnnuhu [Teodozja] 1876. O kongregacji pisał jeszcze w Paryżu w 1857 roku.

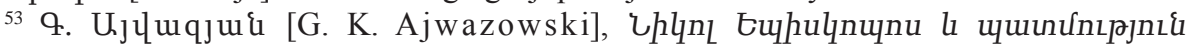

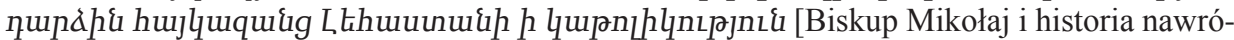
cenia Ormian polskich na katolicyzm], પunup2uuuuun [Eczmiadzyn] 1877.

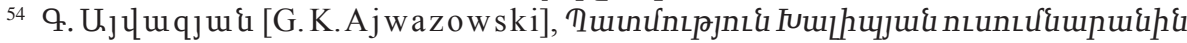
uqqhu huing 1858-1871 [Historia narodowego kolegium ormiańskiego Chalibiana 18581871], Shłuһu [Tyflis] 1880.

${ }_{55}$ Zob. np. [Г. К. Айвазовский], Армянские надписи, находящиеся на юге России, „Записки Одесского общества истории и древностей”, 1867, 6, s. 323-332; i d em, Заметка о происхождении новороссийских армян, ibidem, s. 550-555.

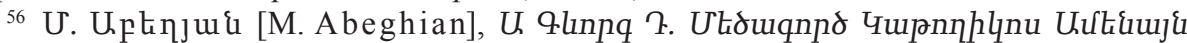
zujng [Gevorg IV Wielki Katolikos Wszystkich Ormian], Eqưurłh\{ [Eczmiadzyn] 2014, s. 90, 172, 256 (praca napisana w 1889 roku).

57 Ш. Хачатрян, Апостол просвещения, „Ноев Ковчег”, 2012, 11 (194), korzystałem z wersji elektronicznej: https://noev-kovcheg.ru/mag/2012-11/3296.html. 
od niego pracę o. Barącza, poświęconą „sławnym Ormianom w Polsce”. Potem musieli jeszcze nieraz wymieniać listy między sobą, o czym wspomina Bogdanowicz w korespondencji z Barączem z 2 września 1874 roku, dodając, że Ajwazowski zapraszał go na $\mathrm{Krym}^{58}$. W następnym liście, z 20 października tego roku, Bogdanowicz pisał, że zamierza wysłać swemu korespondentowi Rys dziejów ormiańskich Barącza, i przybliżał jego sylwetkę oraz dokonania edukacyjne w Teodozji ${ }^{59}$. $\mathrm{O}$, światłym prałacie” Ajwazowskim pisał również w długim liście do arcybiskupa lwowskiego obrządku ormiańskiego Izaaka Mikołaja Isakowicza, wspominając, że otrzymał od niego fotograficzne podobizny różnych osobistości ormiańskich $^{60}$.

W liście do Barącza Ajwazowski wyrażał uznanie i podziw dla jego pracy naukowej, choć może było w tym też trochę kurtuazji. Stwierdził, iż pojawiające się $\mathrm{w}$ tych pracach błędy wynikają przede wszystkich z nieznajomości języka ormiańskiego i dlatego są ,wybaczalne”. W biografii arcybiskupa Mikołaja Torosowicza swego autorstwa chwalił patriotyzm ormiański Barącza, jednak stwierdzał, że jego ujęcie postaci twórcy unii kościelnej Ormian polskich jest skażone „rzymskimi ideami”, stąd niewolne od uprzedzeń i stronniczości ${ }^{61}$.

List do Barącza dotyczył głównie genealogii rodziny Ajwazowskich. W zasadzie był to główny powód, dla którego hierarcha pisał. Warto się zatem zatrzymać nad tym zagadnieniem, tym bardziej że ormiańscy i rosyjscy autorzy, którzy korzystali z listu, nie znali źródeł wytworzonych w Polsce, gdzie żyli i działali przodkowie braci Ajwazowskich. Jeszcze za ich życia pojawiła się teza, iż płynęła w nich krew nie ormiańska, lecz turecka, a ich przodkowie byli wyznawcami Koranu. Tak pisał w 1878 roku rosyjski aktor, teatrolog i pisarz Piotr Karatygin, twierdząc, że informacja ta pochodzi bezpośrednio od Iwana Ajwazowskiego, stąd ma charakter autobiograficzny. Według niego przodkowie artysty przybyli do Galicji z Turcji, otrzymali nobilitację od cesarzy austriackich, a właściciele ziemscy noszący nazwisko Ajwaz lub Hajwaz mieszkają nadal w okolicach Lwowa. Od niego również dowiadujemy się, że pierwotne nazwisko Gajwazowski (Гайвазовский) Iwan i jego bracia zmienili w 1840 roku pod wpływem odkrywania swoich korzeni na Ajwazowski (Айвазовский), jako „bardziej poprawne”62.

58 BZNiO: sygn. 2756 II, korespondencja S. Barącza, 1, s. 445-446.

59 Ibidem, s. 451-452.

${ }^{60}$ Центральний державний історичний архів України, м. Львів: ф. 475, оп. 1, спр. 26, list R. Bogdanowicza arcybiskupa I. Isakowicza, Litiatyn, 3 lutego 1877, k. 4.

${ }^{61}$ „Biografia Mikołaja Torosowicza znajduje się również w cennej książce Żywoty sławnych Ormian w Polsce, wydanej w języku polskim w 1856 roku we Lwowie. Jej autorem jest ormiański dominikanin, ks. Sadok Barącz (to jest Baronian), którego niewątpliwy patriotyzm został następnie pokonany przez jego rzymskie idee, stąd nie był on w stanie uwolnić się od uprzedzeń i stronniczości, zwłaszcza w tych partiach swojej pracy, które dotyczą religii”"

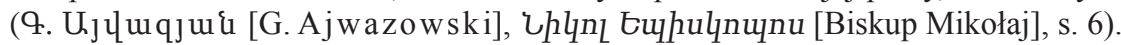

62 П. П. Каратыгин, Иванъ Константиновичъ Айвазовскій, 21, s. 652-653. 
Stało się to w Wenecji, gdzie bracia spotkali się po długiej rozłące, tego właśnie roku zmarł ich ojciec.

Podobnie twierdził Nikołaj Kuzmin: „A w żyłach Ajwazowskiego płynęła turecka krew, chociaż z jakiegoś powodu nadal uważaliśmy ją za krew ormiańską", co - jego zdaniem - wynikało z sympatii, jaką się cieszył ${ }^{63}$. Powoływał się przy tym na osobistą wypowiedź Iwana Ajwazowskiego:

Urodziłem się w mieście Teodozji w 1817 roku, ale prawdziwa ojczyzna moich bliskich przodków, mojego ojca, była daleko stąd, a nie w Rosji. Kto by pomyślał, że wojna - ta plaga niszcząca wszystko, służyła temu, że moje życie zostało zachowane i że ujrzałem światło i urodziłem się dokładnie nad brzegiem mojego ukochanego Morza Czarnego. A jednak tak było. W 1770 roku wojska rosyjskie pod dowództwem Rumiancewa $^{64}$ oblegały Bendery ${ }^{65}$. Twierdza została zdobyta, a żołnierze rosyjscy, zirytowani uporczywym oporem i śmiercią swoich towarzyszy, rozbiegli się po mieście i, kierując się jedynie zemstą, nie szczędzili ani płci, ani wieku. Wśród ich ofiar był sekretarz paszy benderowskiego. Śmiertelnie ugodzony przez jednego z rosyjskich grenadierów, krwawił, ściskając niemowlę, które czekał ten sam los. Już nad małym Turkiem wzniósł się rosyjski bagnet, gdy jeden Ormianin powściągnął karzącą rękę, krzycząc: „Zatrzymaj się! To mój syn! Jest chrześcijaninem!”. Szlachetne kłamstwo było zbawienne i dziecko zostało oszczędzone. To dziecko stało się moim ojcem. Dobry Ormianin nie skończył na tym swojego dobrego uczynku, został drugim ojcem muzułmańskiego sieroty, ochrzcił go imieniem Konstantyn i nadał mu nazwisko Gajwazowskij, od słowa Gajzow, co po turecku oznacza sekretarz. Przeżywszy długi czas ze swoim dobroczyńcą w Galicji, Konstantyn Ajwazowski ostatecznie osiadł w Teodozji, gdzie poślubił młodą, południową piękność, również Ormiankę, i po raz pierwszy zajął się z powodzeniem operacjami handlowymi ${ }^{66}$.

Nie spotkałem się z podobnymi opiniami odnośnie do arcybiskupa Gabriela Ajwazowskiego, co jednak nie wyklucza, że takowych nie było. Możliwe, że z uwagi na te pogłoski zależało mu na odnalezieniu krewnych w Galicji, aby na dobre zakończyć spekulacje.

Wątpliwości co do ormiańskich korzeni braci Ajwazowskich nie mają badacze ormiańscy, podkreślając ich czysto ormiański rodowód, troskę o narodowość i kulturę ormiańską oraz zaangażowanie na rzecz Kościoła i społeczności

${ }^{63}$ Н. Н. Кузьминъ, Воспомінанія объ И. К. Айвазовскомъ, С.-Петербургъ 1901, s. 6.

${ }^{64}$ Chodzi o Piotra Rumiancewa (1725-1796), rosyjskiego generała-feldmarszałka.

${ }^{65} \mathrm{~W}$ Benderach na prawym brzegu Dniestru (dzisiejsza wschodnia Mołdawia) znajdowała się XVI-wieczna twierdza. Jej oblężenie trwało dwa miesiące i obie strony - rosyjska i turecka - poniosły znaczne straty w ludziach.

${ }^{66}$ Н. Н. Кузьминъ, Воспомінанія, s. 8. 
ormiańskich, zarówno w Rosji i imperium osmańskim, jak i diasporze. Podkreślają, że sugestie o tureckich korzeniach Ajwazowskich należy wiązać z panującą wówczas niechęcią władz i społeczności tureckiej do mniejszości ormiańskiej. Ich zdaniem elity rosyjskie przypisywały Iwanowi Ajwazowskiemu pochodzenie tureckie, chcąc przypodobać się Turcji. Jednak sam malarz i jego rodzeństwo czuli się Ormianami i byli przekonani, że mają ormiańskie korzenie. Artysta, choć cieszył się ogromną popularnością i uznaniem w państwie osmańskim, na każdym kroku przypominał o ormiańskim pochodzeniu, wszędzie, a szczególnie w Rosji i Turcji, wspierał swoich rodaków, potępiał ich eksterminację przez państwo osmańskie. Miał, na znak protestu przeciwko tyranii sułtana, wyrzucić wszystkie tureckie medale do morza i spotkawszy konsula tureckiego, powiedzieć: „Wrzuciłem do morza nagrody twojego krwawego pana, oto ich wstążki, wyślij je mu. Jeśli chce, niech wrzuci też do morza moje obrazy, ale to nie jest moje zmartwienie" 67 .

W liście do Barącza arcybiskup pisał o galicyjskim pochodzeniu i przypadkach życiowych swego ojca, Kajetana, wspomniał również stryja Grzegorza, szefa batalionu huzarów w armii austriackiej za czasów cesarzowej Marii Teresy. Podkreślił, że informacje te usłyszał od ojca, który opowiadał dzieciom, że mają kuzynów na Bukowinie i w Galicji. Wymienił także Nersesa, Stefana i Mikołaja Ajwasów, którzy jeszcze w XVIII wieku osiedli na Bukowinie, a o których istnieniu dowiedział się już nie z przekazu rodzinnego, ale z prac Barącza. Faktycznie czytamy w nich ${ }^{68}$, że byli oni synami Grzegorza, a wnukami Nersesa, starosty w księstwie mołdawskim. Zajmowali się handlem, zbudowali kamienicę w Czerniowcach, a w 1789 roku za pozwoleniem władz austriackich kupili dobra ziemskie Mitków na Bukowinie i 7 kwietnia 1790 roku zostali wpisani do Stanów Galicyjskich, co oznaczało uznanie ich szlachectwa. W 1875 roku Ajwazowski nie wykluczał, że mogli jeszcze żyć, co raczej było niemożliwe. Pytał również o Grzegorza Ajwasa, który był członkiem komitetu budowy kościoła ormiańskokatolickiego w Czerniowcach w tym czasie. Pisząc do Barącza, nie wiedział, czy można uznać ich za jego krewnych. Jednak dwa lata później, 25 marca 1877 roku, w liście w języku ormiańskim do Bohosa (Pawła) Ajwasa z Suczawy, był już tego pewny. Pisał, że został o tym poinformowany, ale nie precyzował źródła informacji. Nie jest wykluczone, że nadal chodziło mu o dane zaczerpnię-

${ }^{67}$ Cyt. za: В. А. Микаелян, И. К. Айвазовский и его соотечественники, s. 62; por.

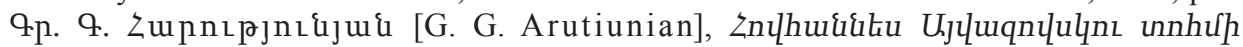

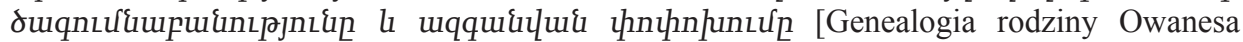
Ajwazowskiego i modyfikacja nazwiska], „ZUUก qU. Stinţuqhp huuupulquiluw qhunnıpjnıqutpph" [Biuletyn Nauk Społecznych AN ASRS], 1965, 2, s. 91; L. Marchand, G. Perrier, Turkey and the Armenian Ghost: On the Trail of the Genocide, thum. D. Bly the, Montreal-London-Ithaca 2015, s. 129.

${ }^{68}$ S. Barąc z, Żywoty sławnych Ormian w Polsce, Lwów 1856, s. 7-8; idem, Rys dziejów ormiańskich, Tarnopol 1869, s. 81. 
te z książek Barącza. Krewni ci mieli przenieść się z Czerniowiec do Suczawy i w jej okolicy zakupić dobra, natomiast w Czerniowcach pozostał Grzegorz Ajwas. Ajwazowski w cytowanym liście z przekonaniem stwierdzał, że obie te rodziny Ajwasów (Hajwasów) - suczawska i czerniowiecka - są ze sobą i z jego rodziną spokrewnione ${ }^{69}$.

Próbę weryfikacji tradycji rodzinnej Ajwazowskich można podjąć, opierając się na ormiańskokatolickich księgach metrykalnych z terenów archidiecezji lwowskiej, które zachowały się i obecnie znajdują się w Archiwum Fundacji Kultury i Dziedzictwa Ormian Polskich w Warszawie. Ponieważ jednak nie mamy kompletu tych ksiąg, weryfikacja nie może być pełna. Najważniejsza wydaje się księga chrztów parafii stanisławowskiej z lat 1703-1783, gdyż ojciec Ajwazowskich, Kajetan, tam miał się urodzić. Wiadomo, że z kolei jego ojciec miał na imię Grzegorz (Grigor), o czym świadczy patronimik używany na modłę rosyjską przez Kajetana - Grigorowicz. Niestety. Brak wpisu chrztu Kajetana Haywasa, względnie Hajwasa, Haywaza, Hajwaza, Aywasa, Ajwasa, Aywaza, Ajwaza, syna Grzegorza. Widnieje tam tylko Kajetan, syn Antoniego Ohanowicza (Janowicza) Haywaza i Marianny z Teodorowiczów, którzy mieszkali w Stanisławowie, w domu pod numerem 19 (potem 16 i 15) ${ }^{70}$. Na świat przyszedł 5 listopada 1776 roku, a następnego dnia otrzymał sakramenty chrztu i bierzmowania w kościele ormiańskokatolickim ${ }^{71}$. Z małżeństwa tego urodziło się jeszcze kilkoro dzieci, jednak żadne z nich nie otrzymało imienia Grzegorz. Kajetana Haywaza z księgi stanisławowskiej nie można utożsamiać z ojcem Gabriela, nawet jeżeli założymy, że w liście Ajwazowskiego i w opracowania rosyjskich i ormiańskich podawane są błędne daty jego urodzenia. Moim zdaniem, w księdze mowa jest o późniejszym adwokacie Sądu Szlacheckiego w Stanisławowie, który ożenił się z Teklą z Mileskich Ortyńską. Mieszkali w domu pod numerem 32 i doczekali się co najmniej sześciorga dzieci ${ }^{72}$.

${ }^{69}$ Oryginał listu znajduje się w Archiwum Narodowym Armenii (Zuujuuuunuuh uqqujh\{ uphuһц) w Erywaniu: ф. 57, on. 1 д. 320, k. 42. Nie miałem jeszcze do niego dostępu. Fragment cytuje M. Sargsjan: Айвазовский. Документы и материаль, s. 312.

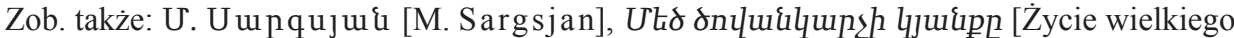
malarza], Epluui [Erywań] 1990, s. 7 (wersja rosyjska: М. С. Саргсян, Жизнь великого мариниста: Иван Константинович Айвазовский, thum. Е. Барашьян, ФеодосияМосква 2010, s. 10-11).

${ }^{70}$ Zmarła 22 kwietnia 1802 roku w wieku 52 lat na suchoty i została pochowana na cmentarzu publicznym; Archiwum Fundacji Kultury i Dziedzictwa Ormian Polskich, dalej AFKiDOP: zespół 9, sygn. 36, Księga zmartych Ormian parafian stanisławowskich (17151829), s. 116.

${ }^{71}$ AFKiDOP: zespół 9, sygn. 24, Księga druga parafian Ormian ochrzczonych w kościele stanisławowskim od roku 1703 [do 1783], s. 246. Chrzestnymi dziecka zostali: porucznik Mikołaj Malwus i Anna Janowa Stefanowiczowa Roszko.

72 Kajetan Haywaz, adwokat sądu szlacheckiego stanisławowskiego, wzmiankowany jest w stanisławowskiej księdze chrztów najpierw jako chrzestny w latach 1819 i 1824. Jego wła- 
Skoro w stanisławowskich księgach metrykalnych (nie tylko chrztów) nie udało się znaleźć żadnego Kajetana syna Grzegorza, być może należy szukać go w metrykach innych parafii ormiańskich na terenie Galicji i Bukowiny. Kwerenda w dostępnych dziś księgach parafialnych nie wykazała jednak osoby, którą można byłoby utożsamić z ojcem arcybiskupa Ajwazowskiego. A należy podkreślić, iż w księgach tych pojawia się wiele osób o nazwiskach Haywas i Aywas lub podobnie brzmiących (Aiwas, Aywaz, Ajwas itd.), które nie wiemy jeszcze, czy dotyczą tej samej rodziny, czy różnych.

Warto jeszcze odnieść się do braci Nersesa, Stefana i Mikołaja Ajwasów, o których pytał arcybiskup. W księgach metrykalnych kilku parafii ormiańskich pojawiają się wprawdzie Ajwasowie o takich imionach, jednak większość z nich urodziła się już w XIX wieku, a więc nie mogą być nimi. W księgach powinny natomiast pojawić się ich dzieci. I tak Mikołaj, syn Grzegorza ze Śniatynia, był chrzestnym w parafii stanisławowskiej w $1769 \mathrm{roku}^{73}$. Mikołaj, dziedzic w Wyżnicy, występuje w księdze chrztów parafii ormiańskokatolickiej w Kutach. Z żoną, Zofią (Zanchirą) Capri (Kapri), miał troje dzieci: Andrzeja (ur. ok. 1797) ${ }^{74}$, Ste-

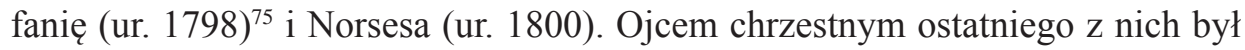
Stefan Aywaz, również dziedzic w Wyżnicy, zapewne brat Mikołaja ${ }^{76}$. Możliwe, że znajdujemy w metrykach parafii śniatyńskiej kolejnego brata, Nersesa. Odnotowany jest w nich bowiem Norses (!), mąż Marianny Mikuli, ojciec Jana (ur. ok. 1789) i Brygidy (ur. ok. 1808)77. Można przypuszczać, że to właśnie o nich mowa była w pracy Barącza i w liście Ajwazowskiego.

Aywazów, właścicieli Mitkowa, Wyżnicy i Synowców, jest znacznie więcej w badanych księgach parafialnych. Jest wśród nich kilku Grzegorzów. W księdze zgonów parafii czerniowieckiej odnotowano w 1851 roku śmierć Grzegorza, dziedzica Mitkowa, w wieku 70 lat $^{78}$. Jeżeli urodził się około 1781 roku, nie

sne dzieci rodziły się od 1824 do 1834 roku. Por. AFKiDOP: zespół 9, sygn. 36, Księga zmarbych Ormian parafian stanisławowskich (1715-1829), s. 152.

73 „Filius Gregorii Haywaz Civ. Sniat. Arm.” (AFKiDOP: zespół 9, sygn. 24, Księga druga, s. 218).

${ }^{74}$ Andrzej Aywas, dziedzic w Synowcach, w 1833 roku, jako 36-latek, ożenił się z 19-letnią Rozalią Mikuli, córką Jakuba i Katarzyny z Jakubowiczów, dziedziców w Wastowcach (Wirtualne Archiwum Polskich Ormian, dalej: WAPO): księga małżeństw ormiańskokatolickiej parafii w Śniatyniu, http://www.archiwum.ormianie.pl/archiwumk.php. Zmarł w 1858 roku, a jego żona w 1878 roku (WAPO: księga zmarłych ormiańskokatolickiej parafii w Czerniowcach). Mieli córki: Stefanię (ur. ok. 1839) i Zofię (rok młodsza) oraz syna Grzegorza (ur. ok. 1841).

75 Stefania Aywas w 1828 roku wyszła za Deodata de Oroszeny Bogdanowicza (WAPO: księga małżeństw parafii ormiańskokatolickiej w Kutach z lat 1780-1848).

76 WAPO: księga chrztów parafii ormiańskokatolickiej w Kutach z lat 1780-1848.

77 Jan Aywaz w 1835 roku ożenił się z Marianną Zadurowicz, a Brygida Aywas w 1834 roku wyszła za Hipolita Duczellewicza, przynależnego do obrządku łacińskiego (WAPO: księga małżeństw ormiańskokatolickiej parafii w Śniatyniu).

${ }^{78}$ WAPO: księga zmarłych ormiańskokatolickiej parafii w Czerniowcach. 
można go uznać za stryja arcybiskupa, służącego w armii austriackiej za panowania cesarzowej Marii Teresy. Grzegorz, ten sam lub inny, był mężem Józefiny Zawirskiej, z którą miał synów: Apolinarego (ur. ok. 1834) i Emila (ur. 31 lipca 1836). W 1863 roku 27-letni Apolinary ożenił się z Katarzyną Missir, córką Jerzego Missira i Marii Kapri ${ }^{79}$. Z kolei jako mąż Katarzyny Missar figuruje w księdze zgonów parafii czerniowieckiej Hipolit Aywas. Ponieważ zmarł w 1882 roku w wieku 48 lat $^{80}$, można zakładać, że chodzi tu jednak o Apolinarego. Emil Aywas natomiast ożenił się w 1870 roku z Rozalią Hankiewicz ${ }^{81}$. Miał z nią dwie córki: Kajetannę i Antoninę. Pod rokiem 1840 w czerniowieckiej księdze chrztów mowa jest również o dzieciach Grzegorza „de Aiwas”, dziedzica Mitkowa: Nersesie (ur. 1815) i Mariannie (ur. 1817). Ich matką była Antonina Torosiewicz, córka Kajetana i Tekli, dziedziców w Sopowie. W 1845 roku Marianna wyszła za dziesięć lat starszego Jana Janowicza, właściciela majątku w Werbowcach ${ }^{82}$. Rok później urodziła się im córka Rozalia ${ }^{83}$, która w wieku 17 lat zawarła związek małżeński z Szymonem Barączem, bratankiem o. Sadoka (syna jego brata Karola) ${ }^{84}$. Jak z tego wynika, rodzina Aywasów musiała być prywatnie znana o. Barączowi. Kolejny Grzegorz Aywas - to syn wspomnianego już Andrzeja. Po ojcu był dziedzicem w Synowcach i w Wyżnicach, ponadto posiadał tytuł kawalera Orderu Żelaznej Korony. W 1869 roku, w wieku 28 lat, zawarł związek małżeński z 19-letnią Ludwiką Nikorowicz, córką Pawła i Julii z Nahajowskich, właścicieli dóbr w Hostowie ${ }^{85}$. Nie jest pewne, czy ten ostatni Grzegorz był tożsamy z członkiem komitetu budującego kościół ormiańskokatolicki w Czerniowcach, o którego zapytywał arcybiskup w liście do o. Barącza ${ }^{86}$, interesując się przy tym losami tej budowli ${ }^{87}$.

79 WAPO: księga zapowiedzi parafii ormiańskokatolickiej w Czerniowcach z lat 18611915.

${ }^{80}$ WAPO: księga zmarłych parafii ormiańskokatolickiej w Czerniowcach.

81 WAPO: księga małżeństw ormiańskokatolickiej parafii w Horodence.

82 Świadkami na ślubie byli: Grzegorz Ajwas, dzierżawca w Werenczance, i Narcyz Aywas, dzierżawca w Filipkowcach (WAPO: księga małżeństw parafii ormiańskokatolickiej w Czerniowcach).

${ }^{83}$ WAPO: księga urodzonych parafii ormiańskokatolickiej w Czerniowcach. Jej chrzestnymi byli: Grzegorz Aiwas, dziedzic w Mitkowie (dziadek), i Elżbieta, żona Grzegorza „de Aiwas", właściciela majątku w Werenczance.

${ }^{84}$ AFKiDOP: zespół 9, sygn. 1, Księga zapowiedzi parafii ormiańskokatolickiej w Czerniowcach z lat 1861-1915, s. 3-4.

${ }^{85}$ WAPO: księga zapowiedzi parafii ormiańskokatolickiej w Kutach; F. Wasyl, Ormianie $w$ świetle zapowiedzi przedmatżeńskich rodzimej parafii w Kutach, „Krakowskie Pismo Kresowe", 8 (2016), s. 122.

${ }^{86}$ Komitet Budowy Kościoła Ormiańskokatolickiego w Czerniowcach powstał w 1864 roku. Jego przewodniczącym był Jakub Petrowicz (1815-1869), burmistrz tego miasta. Sygnatariuszami odezwy wystosowanej przez komitet byli ormiańscy ziemianie z Bukowiny: Grzegorz Aywas, Jakub Petrowicz, Michał Warteresiewicz, Ludwik Mikuli, Jakub Simono- 
Jeszcze jeden członek rodziny, którego arcybiskup - jak pisze - miał okazję poznać, to ks. Filip Hajwas (1802-1865). Urodził się w Śniatyniu, teologię studiował we Lwowie, został wyświęcony na kapłana w obrządku ormiańskokatolickim w 1826 roku, potem był wikarym w parafii katedralnej, kuratorem szkoły benedyktynek ormiańskich i kasjerem w banku „Mons Pius” we Lwowie, a w 1837 roku objął parafię w Stanisławowie, gdzie zmarł ${ }^{88}$.

Badania nad genealogią rodzin Hajwasów / Ajwasów, a także ich przemieszczaniem się oraz rolą, jaką odegrali w życiu społecznym, kulturalnym i religijnym Galicji i Bukowiny, wymagają kontynuacji. Nadawanie tych samych imion w jednej rodzinie bardzo komplikuje poszukiwania. Dodatkowo utrudnia je brak kompletu ksiąg metrykalnych. A trzeba też mieć na uwadze to, że niektórzy Ajwazowie, zwłaszcza na terenie Bukowiny, nie należeli do Kościoła ormiańskokatolickiego, lecz narodowego.

\section{Aneks}

\section{List arcybiskupa Gabriela Ajwazowskiego do ojca Sadoka Barącza}

Mon Révérend Père.

Très cher frère en Jésus - Christ!

Si je prends la liberté de vous importuner par une lettre sans avoir le plaisir de vous connaître personnellement, c'est par suite des éloges que me fait constamment de votre bonté et de vos travaux, notre ami commun Mr le Cher Robert de RoskoBogdanovitch. Je me trouvais encore à Paris, il y a 18 ans, lorsque j'ai reçu de lui un exemplaire de votre bel ouvrage intitulé: «Żywoty Ormian».
Mój Przewielebny Ojcze.

Najdroższy Bracie w Jezusie Chrystusie!

Jeśli pozwalam sobie naprzykrzać się przez ten list, nie mając przyjemności poznania Was osobiście, to na skutek pochwał, jakie stale czyni o waszej dobroci i waszych pracach nasz wspólny znajomy, drogi Pan Robert de Rosko-Bogdanowicz. Byłem jeszcze w Paryżu 18 lat temu, gdy otrzymałem od niego egzemplarz waszego pięknego dzieła zatytułowanego: „Żywoty Ormian".

wicz, Grzegorz Bogdanowicz, Antoni Zadurowicz, Łazarz Passakas i Mikołaj Negrusz, a jej właściwym autorem był proboszcz ormiańskokatolicki w Czerniowcach, ks. Florian Mitulski-Wartanowicz (S. B arącz, Rys, s. 82-84; A. A. Zięba, Przemiany tożsamości narodowej Ormian $w$ dobie walk o niepodległość Polski, schytek XVIII - poczatek XXI wieku, w: Polscy Ormianie $w$ drodze do niepodległej Polski. Materiały z konferencji naukowej. Kraków, 9-10 października 2018 r., red. S. Dziedzic, J. Paluch, Kraków 2018, s. 28).

87 W chwili pisania listu ormiańskokatolicki kościół św. Grzegorza Oświeciciela w Czerniowcach był już na ukończeniu, jego konsekracja miała miejsce 9 października 1875 roku. Świątynia powstała według projektu czeskiego architekta Josefa Hlávka (В. Безякін, Peставрація та пристосування вірменської иеркви в Чернівиях, w: 3 історії украӥнської реставраціï, red. В. Тимофієнко, Київ 1996, s. 139-142).

${ }^{88}$ T. Zaleski, Stownik biograficzny duchownych ormiańskokatolickich oraz duchownych rzymskokatolickich pochodzenia ormiańskiego w Polsce w latach 1750-2000, Kraków 2001, s. 49. 
Le polonais ne m'étant pas aussi familier que quelques autres langues anciennes et modernes, j'ai eu d'abord assez de difficulté pour bien comprendre et apprécier votre travail, si précieux pour tout armenien dévoué à sa nationalité. L'ardent désir de connaître à fond tout ce qui regarde le passé et le présent de nos pères et confrères polonisés depuis deux siècles et demi, m'engagea à étudier leur langage actuel, au moins autant que me permettaient de le faire mes occupations toujours croissantes; j' en ai même traduit quelques biographies et publié dans mon journal «Massiatz-Aghawni» (La Colombé d'Ararat), que je rédigeait mensuellement en armenien et en français.

Je suis charmé maintenant d' avoir reçu dans ces jours-ci, de la part de $\mathrm{Mr}$ Bogdanovitch, votre ouvrage «Rys Dziejów Ormiańskich»; je l'ai parcouru avec beaucoup d'intérêt et de plaisir, et sauf certaines inexactitudes, - d'ailleurs très excusables pour un auteur qui ne connaît pas l'armenien, - j'y ai partout aperçu un amour très chaleureux pour tout ce qui a du rapport avec notre histoire, géographie, littérature, moeures et usages, anciens et modernes, civils et religieux. Je vous en félicite et remercie, Très Rév. Père.

Permettez-moi cependant, bon Père, de vous adresser une prière. Vous savez sans doute que mon nom de famille (dont vous faites mention à la page 205 de votre «Rys») provient de celui des Haiwaz ou Aywas, dont vous parlez dans vos ouvrages. Or, mon père (Cajetan, en Russie Constantin et Kévork ou Georges) né à Stanislwow vers l'an 1765 ou 1766, immigré en Moldavie, ensuite en Crimée au commencement de ce siècle, décédé ici en 1840, nous disait souvent qu'il y a des parents ou des cousins en Boukowine et en Galicie, et que son frère ainé, Grégoire,
Język polski, nie będąc mi znany tak jak kilka innych języków starożytnych i nowoczesnych, sprawiał mi trudności, by dobrze zrozumieć i ocenić waszą pracę, tak cenną dla każdego Ormianina przywiązanego do swej tożsamości narodowej. Gorące pragnienie gruntownego poznania wszystkiego, co dotyczy przeszłości i teraźniejszości naszych spolonizowanych od dwóch i pół wieku ojców i braci, zaangażowało mnie w studia ich aktualnego języka, co najmniej tak, jak pozwalają mi na to coraz większe zajęcia. Przetłumaczyłem nawet kilka biografii i opublikowałem w moim czasopiśmie „Massiatz - Aghawni" (Gołębica z Araratu), który wydawałem co miesiąc w języku ormiańskim i francuskim.

Obecnie jestem oczarowany waszym dziełem „Rys dziejów ormiańskich”, otrzymanym w tych dniach od Pana Bogdanowicza. Przejrzałem je z wielkim zainteresowaniem i przyjemnością, z wyjątkiem pewnych nieścisłości - zresztą całkiem wybaczalnych wobec autora, który nie zna języka ormiańskiego - wszędzie doceniłem bardzo gorącą miłość do wszystkiego, co odnosi się do naszej historii, geografii, literatury, obyczaju i zwyczajów, dawnych i współczesnych, świeckich i religijnych.

Gratuluję Wam i dziękuję, Przewielebny Ojcze. Jednak proszę mi pozwolić, dobry Ojcze, skierować do Was jedną prośbę. Niewątpliwie Ojciec wie, że moje nazwisko rodowe (o czym jest wzmianka na stronie 205 waszego „Rysu”) pochodzi od Haiwaz lub Aywas, o czym Ojciec mówi w swoich dziełach. Otóż, mój ojciec (Kajetan, w Rosji Konstantyn i Kework lub Jerzy), urodzony w Stanisławowie w 1765 lub 1766, imigrant w Mołdawii, a następnie na Krymie w początku tego wieku, zmarły tutaj w 1840, często nam mówił, że ma przodków lub 
avait servi dans l'armée autrichienne, sous Marie-Thérèse, en qualité de chef de bataillon des houssars, etc. En passant par la Boukowine en 1841, j'ai rencontré à Czernowitz le P. Filip Hajwas, curé de Stanislawow (p. 170), mais, malgré le grand plaisir d'avoir fait sa connaissance, je n'ai pu recevoir de lui des renseignemets complets ou satisfaisants au sujet de la généalogie des Haïwaz. Par conséquant, vous me rendriez un grand service, mon Rév. Père, si vous vouliez vous mettre en correspondance directe avec les restes de cette famille, obtenir de ces messieurs des notices positives sur leurs ancêtres, leur généalogie et leurs traditions de famille. Les Haïwaz de Czernowitz (Norsès, Stefan et Nicolas) vivent-ils encore? (s. 81), et Mr Grzegorz Aywas, membre du Comité de la construction d'une église armenienne à Czernowitz, s'y trouve-t-il encore? Où en est-on avec la construction de cette église? etc.

J'ose espérer, mon cher frère en J. C., que vous voudrez bien me donner une prompte réponse, et je vous prie d'agréer d'avance mes remerciements et l'expression des sentiments fraternels avec lesquels je me recommande à vos prières, et je me dis,

Très Rév. Père,

Votre très humble serviteur

+ Gabriel Aiwazovsky, archevêque

(Membre du Synode d' Etchmiadzine)

Théodosie (Kaffa) en Crimée

Ce 25 Janvier (6 févr.) 1875

P. S. Je serai sans doute très content si vous vouliez $\mathrm{m}$ 'écrire en français, en italien ou en latin ; mais je comprends maintenant assez le polonais pour que vous puissiez entrer librement avec moi en correspondance dans cette langue. kuzynów na Bukowinie i w Galicji, oraz że jego najstarszy brat, Grzegorz, służył w austriackiej armii pod Marią Teresą, jako dowódca batalionu huzarów etc. Przejeżdżając przez Bukowinę w 1841, spotkałem w Czerniowcach o. Filipa Hajwasa, proboszcza w Stanisławowie (s. 170), ale mimo wielkiej przyjemności z zapoznania się z nim, nie otrzymałem od niego informacji pełnych ani zadowalających na temat genealogii rodu Hajwaz. Wobec tego wyświadczy mi Wielebny Ojciec wielką przysługę, jeśli zechce nawiązać bezpośrednią korespondencję z pozostałymi z tej rodziny i otrzymać od tych panów realne dane o przodkach, ich genealogii oraz ich tradycjach rodzinnych. Członkowie rodziny Hajwaz z Czerniowiec (Norses, Stefan i Mikołaj), czy jeszcze żyją? (s. 81), a pan Grzegorz Aywas, członek Komitetu Budowy Kościoła Ormiańskiego w Czerniowcach, czy jeszcze tam przebywa? Jak daleko posunięta jest budowa tego kościoła? etc.

Śmiem ufać, mój drogi bracie w Jezusie Chrystusie, że zechcesz mi dać rychłą odpowiedź, i proszę z góry przyjąć moje podziękowania i wyraz braterskich serdeczności, z jakimi polecam się waszym modlitwom, uznając się,

Przewielebny Ojcze,

Waszym najpokorniejszym sługą

+ Gabriel Awazowsky, arcybiskup

(Członek Synodu w Eczmiadzynie)

Teodozja (Kaffa) na Krymie

25 stycznia (6 lutego) 1875

P.S. Niewątpliwie będę bardzo zadowolony, jeśli zechcecie mi napisać po francusku, włosku lub po łacinie; ale obecnie dość dobrze rozumiem język polski, abyście mogli swobodnie korespondować ze mną w tym języku. 


\section{Bibliografia}

\section{Źródła rękopiśmienne:}

Archiwum Fundacji Kultury i Dziedzictwa Ormian Polskich: zespół 9, sygn. 1, Księga zapowiedzi parafii ormiańskokatolickiej w Czerniowcach z lat 1861-1915; sygn. 24, Księga druga parafian Ormian ochrzczonych $w$ kościele stanisławowskim od roku 1703; sygn. 25, Księga trzecia ochrzczonych w kościele stanisławowskim parafian ormiańskich od roku 1703; sygn. 26, Index nazwisk z ksiag ślubów parafii ormiańsko-katolickiej w Stanisławowie. Księga ślubów 1785-1836

Biblioteka Zakładu Narodowego im. Ossolińskich we Wrocławiu: sygn. 2756

[Centralnyj] Ц ентральний державний історичний архів України, м. Львів: ф. 475, оп. 1, спр. 26

\section{Źródła drukowane:}

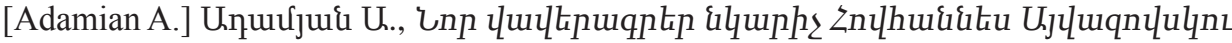
Uuuhq [Nowe dokumenty o artyście Iwanie Ajwazowskim], „ZUUก qu

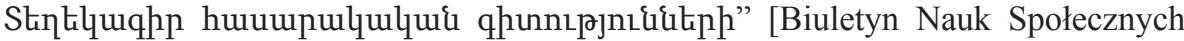
Akademii Nauk ASRR], 1958, 11

[Ajwazowski] Айвазовский. Документы и материаль, орrac. М. С. Саргсян, Г. Г. Арутюнян, Г. М. Шатирян, red. 3. Г. Башинджагяна, Ереван 1967

[Ajwazowski G.] [Айвазовский Г.], Армянские надписи, находящиеся на юге России, „Записки Одесского общества истории и древностей”, 1867, 6, s. 323-332

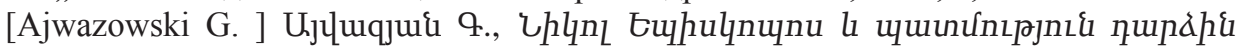

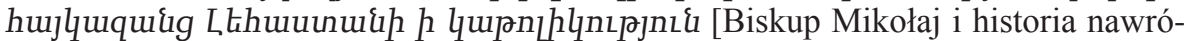
cenia Ormian polskich na katolicyzm], પ,unupzuuuuun [Eczmiadzyn] 1877

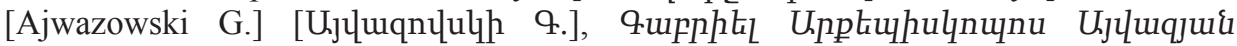
(U.jluqnuluh). 1812-1879. Curnpuih [Gabriel arcybiskup Ajwazjan (Ajwazow-

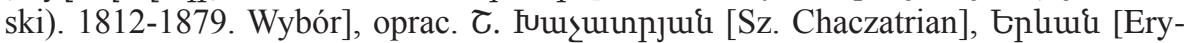
wań] 2012

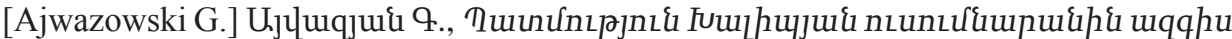
hujng 1858-1871 [Historia narodowego kolegium ormiańskiego Chalibiana 18581871], Shłupu [Tyflis] 1880

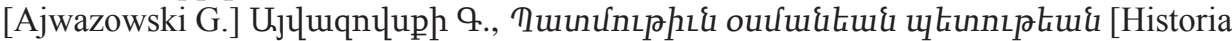
imperium osmańskiego], 1-2, પ̧,titiunhl [Wenecja] 1841

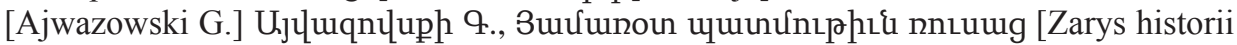
Rosji], પ,tiktiunpl [Wenecja] 1836

[Ajwazowski G.] [Айвазовский Г.], Заметка о происхождении новороссийских армян, „Записки Одесского общества истории и древностей”, 1867, 6, s. 550-555

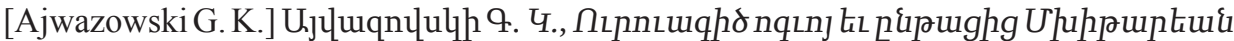
uhupuinıpłui [Zarys ducha i historii Kongregacji Mechitarystów], مُŁnnnuhu [Teodozja] 1876

[Kuzmin] Кузьминъ Н. Н., Воспомінанія объ И. К. Айвазовскомъ, С.-Петербургъ 1901

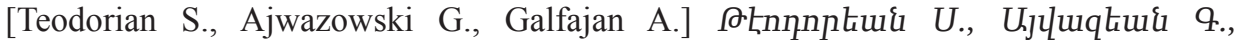

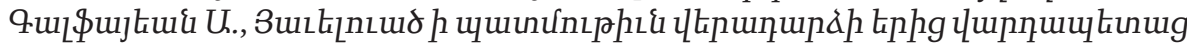

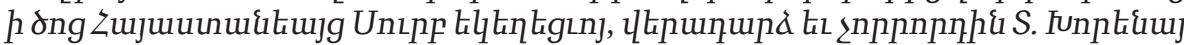

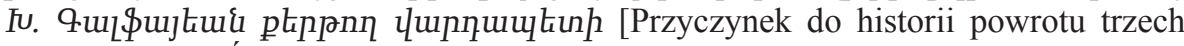
wardapetów do Świętego Kościoła Ormiańskiego, powrót i czwartego T[er] Chorena Ch. Galfajana], Фuuphq [Paryż] 1858 


\section{Opracowania:}

[Abeghian M.] Uptinjuiq U., U qlinpq ?. Utiduqnpd Gupnnhlinu Uuftiujf Zujng [Gevorg IV Wielki Katolikos Wszystkich Ormian], Eqưurdh\& [Eczmiadzyn] 2014

[Ajwazowskij] Айвазовскій Гавріиль Константиновичъ, w: Русскій біографическій словарь, 1, С.-Петербургъ 1896, s. 87-88

[Aradżioni M. A.] Араджиони М. А., Формирование армянских общин в восточном Крыму (конеи XVIII - первая половина XIX веков), „Исследования по арменистике в Украине", 1, 2008, s. 79-93

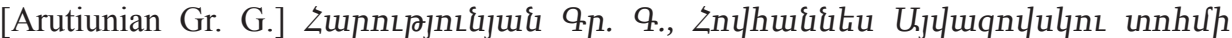

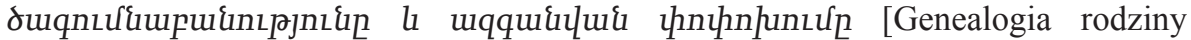
Owanesa Ajwazowskiego i modyfikacja nazwiska], „ZUUก qU Stitiquqhp huuupulquiluiq qhunnıpjnı\&quph" [Biuletyn Nauk Społecznych AN ASRS], 1965,2 , s. 89-94

[Arutiunian L. W.] Арутюнян Л. В., Католики-армяне в Крыму и их вклад в Мировую культуру, „Причерноморье. История, политика, культура”, 2012, 9, s. 8-15

[Awietisjan W. R.] Аветисян B. Р., Институт восточных языков (Лазаревский Институт) как центр русско-армянских взаимоотношений в XIX - первой четверти ХХ вв., Ставрополь 2018 (praca doktorska dostępna w wersji elektronicznej: https://www.ncfu.ru/science/dissertacionnye-sovety/obyavleniya-o-zaschitedissertaciy/avetisyan-vladimir-rudol_fovich/index.html)

[Bagdasarjan M.] Багдасарян М., Семья Айвазовских в Феодосии, [b.m.w.] 2019

[Bagdykow M. G.] Багдыков М. Г., Багдыков Т. М., Арутюн Халибян, Ростов-на-Дону 2011

[Baraszian Je. W.] Барашьян Е. В., Исторический взгляд на судьбу халибовского армянского училища в Феодосии, „Исследования по арменистике в Украине”, 2, 2010, s. $36-40$

Barącz S., Rys dziejów ormiańskich, Tarnopol 1869

Barącz S., Żywoty sławnych Ormian w Polsce, Lwów 1856

[Barsamow N. S.] Барсамов Н. С., Иван Константинович Айвазовский. 1817-1900, Москва 1962

Beledian K., Cinquante ans de littérature arménienne en France. Du même à l'autre, Paris 2001

[Bezjakin W.] Безякін B., Реставрація та пристосування вірменської ичеркви в Чернівиях, w: 3 історії украӥнської реставрації, red. В. Тимофієнко, Київ 1996, s. $139-142$

[Błochin] Блохин В., Этапь и содержание армяно-русского межконфессионального диалога: исторический и современный опыт, „Fuiptip Epluuqh

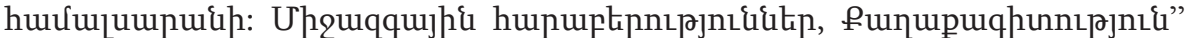
[Biuletyn Uniwersytetu Erywańskiego], seria: Uhouqqu]h\{ hupupknnıpjnı\&qun, Punupuqhunnıpjnı\& [Stosunki międzynarodowe i nauki polityczne], 2019, 1, s. $28-37$

Bournoutian G. A., Russia and the Armenians of Transcaucasia 1797-1889, Costa Mesa 1998

[Bożko O. I.] Божко О. І., Діяльність Габрієла Айвазовського в контексті суспільних проиесів середини ХІХ ст., „Східний світ”, 2012, 4, s. 5-14

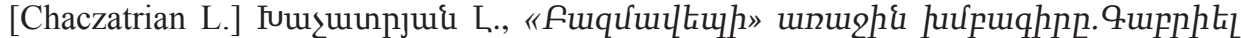
Uıцuqnцulh [Pierwszy redaktor „Bazmavep” Gabriel Ajwazowski], „Yuukptin. 


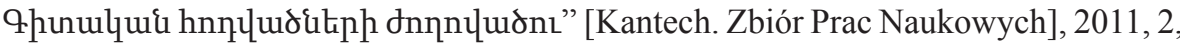
s. $34-40$

[Chaczatrian Sz.] Хачатрян Ш., Апостол просвещчения, „Ноев Ковчег”, 2012, 11 (194)

[Chaczatrian Sz.] Хачатрян Ш., Братья Айвазовськие, „Третьяковская Галерея”, 2016, 4 (53), s. 148-161

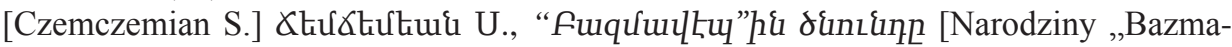
vep”], „Furqưultuu/Bazmavep”, 150, 1994, s. 49-66

Dashkievych J., Matériaux pour l'histoire des colonies arméiennes en Ukraine, se trouvant dans les bibliothéques de Cracovie et de Wroclaw, „Revue des Études arméniennes", 1970, 7, s. 451-465

[Daszkiewicz Ja. R.] Дашкевич Я. Р., Материаль по истории армянских колоний на Украине в библиотеках Кракова и Врощлава, „Вестник Архивов Армении”, 1970,3 , s. $175-186$

[Dawtian D. A.] Давтян Д. A., Творчество армянского архитектора Демосфена Григорьевича Мазирова в Одессе, „Воронцовский сборник”, 4, 2011, s. 21-29

[Dawtian D. A.] Давтян Д. А., Неизвестные страницы жизни архимандрита Гавриила Айвазовского (Габриеля Айвазяна), „Исследования по арменистике в Украине", 1, 2008, s. 106-111

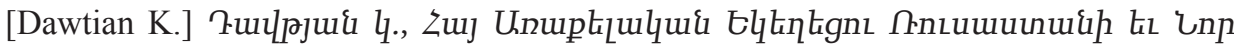

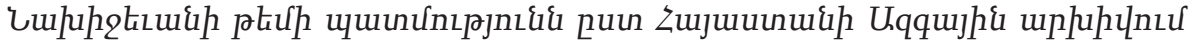

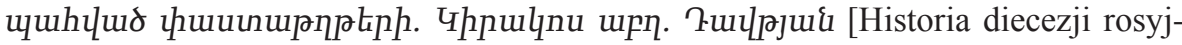
skiej i nowo-nachiczewańskiej Ormiańskiego Kościoła Apostolskiego według dokumentów z Narodowego Archiwum Armenii], „Еqưhurðh\{” [Eczmiadzyn], 72, 2015, 7, s. $134-138$

Etmekjian J., The French Influence on the Western Armenian Renaissance 1843-1915, New York 1964

Ferrari A., Alla Frontiera dell'Impero. Gli armeni in Russia (1801-1917), Milano 2000

Ferrari A., I fratelli Ayvazean / Ajvazovskij tra la Crimea e Venezia, „Annuario dell'instituto Romeno di Cultura e Ricerca Umanistica di Venezia”, 14-15, 2017, s. 185-195

[Garibdżanian S.] Гарибджанян C., Деятели Армянской Церкви (XIX-XX вв.). Биографические очерки, Ереван 2005

[Ginzburg J.] Гинзбург И., Армянские художники первой половины ХІХ в., „, Тuunưpuiquuhpulqui huqntu" [Czasopismo Historyczno-Filologiczne], 1958, 3, s. $106-135$

Gli Armeni e Venezia. Dagli Sceriman a Mechitar. Il momento culminante di una consuetudine millenaria, red. B. L. Zekiyan, A. Ferrari, Venezia 2004

[Grigorian W. R.] Григорян В. Р., История армянских колоний Украины и Польши (Армяне в Подолии), Ереван 1980

[Grigorianc W.] Григорьянц В., Из истории армянской школьы в Крыму, „Сурбхач”, 1998 , 12, s. 5-8

[Grigorianc W. Е.] Григор'ьянц В. С., Вірмени Криму: минуле і сьогодення (Проблеми соиіокультурного та етпополітпчного розвитку), Сімферополь 2005, seria: Серія додатків до паукового журналу „Кримський Архів”

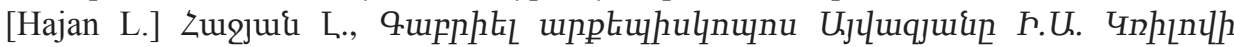
unulqitiph puinquiulhs [Arcybiskup Gabriel Ayvazyan tłumacz bajek Kryłowa], Eqưưłq [Eczmiadzyn] 1976 
[Hajuk I.] Гаюк I., Айвазовский, Григорий Константинович (1801-1881), w: Армяне Причерноморья: энциклопедия, red. И. В. Кузнецов, 1, Москва 2020

[Hajuk I.] Гаюк I., Ілюстрована енциклопедія вірменської культури в Україні: з каталогізованим додатком переліку пам'яток вірменської культури в музеях та заповідниках, 1, Львів 2012

Haroutyunian S., P. Gabriēl Ayvazean: l'editore e il traduttore, w: La Crimea tra Russia, Italia e Impero ottomano, red. A. Ferrari, E. Pupulin, Venezia 2017, seria: Eurasiatica, 8, s. 53-68

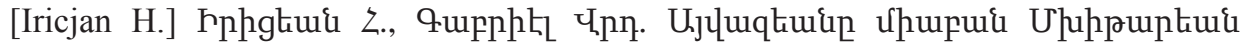
uhupuinıpłum [Ks. Gabriel Aywazowski jako członek Kongregacji Mechitarystów], „Furquul[tux / Bazmavep”, 2017, 3-4, s. 140-162

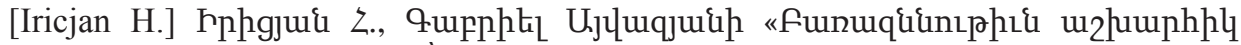

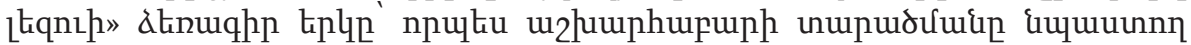
w2huwunnıpjnı\{ [Rękopis Gabriela Ajwazowskiego „Analiza słów języku świeckiego" jako dzieło promujące rozpowszechnianie się współczesnego języka ormiańskiego], „Fuifup Uuuntiqunupuil,” [Biuletyn Matenadaranu], 27, 2019, s. 371-387

[Karatygin P. P.] Каратыгин П. П., Иванъ Константиновичъ Айвазовскій и его XLII-хъ лґтняя художественная дюятельность 1836-1878, „Русская Старина”, 9, 1878, 21, s. 649-674; 22, s. 423-444; 23, s. 55-74, 281-306, 1881; 31, s. 411-436

[Karaułow G.] Караулов Г., Гавриил Айвазовский, архиепископ Армяно-Григорианский, „Записки Імператорского Одесского общества истории и древностей”, 1881, 12, s. 435-443

[Kazarow S. S.] Казаров С. С., Айвазовский, Гавриил Константинович (1812-80), w: Армяне Причерноморья: энииклопедия, red. И. В. Кузнецов, 1, Москва 2020, s. 208-209

Kirmizi A., European Educational Backgrounds of Armenian Officials in the Ottoman Empire, w: Middle Eastern Christians and Europe: Historical Legacies and Present Challenges, red. A. Schmoller, [Zürich 2018], seria: Orientalia - Patristica-Oecumenia, 13, s. 59-77

[Małojan A.] Малоян А., Очерк о духовно-просветительской деятельности НовоНахичеванской и Бессарабской епархии (1830-1918), w: 300 лет Российской и Ново-Нахичеванской епархии Армянской Апостольской Церкви. Исторический путь и современность. Материаль Международной научной конферениии (Москва, 24-25 октября 2017 г.), red. Б. Зулумян, Москва 2018, s. 331-341

Marchand L., Perrier G., Turkey and the Armenian Ghost: on the Trail of the Genocide, thum. D. Blythe, Motreal-London-Ithaca 2015

Mathorez J., Les Arméniens en France: de 1789 à nos jours, „Revue Études Arméniennes", 2, 1922, s. 293-314

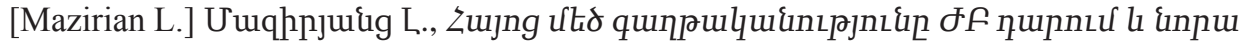
પh夭uly Lthuuunuqnud [Wielka emigracja ormiańska w XII w. i jej sytuacja w Polsce], „Upuupu” [Araks], 1889, 1/7, s. 126-136

[Mazurow L. J.] Мазиров Л. Е., Иван Константинович Айвазовский. По поводу его пятидесятилетнего юбилея, сборник статей из «Правительственного вестника», Санкт-Петербург 1888

[Mikaelian W.] Микаелян В., Габриел Айвазовский (Айвазян), „Голубь Масиса”, $1997,12-14$ 
[Mikaelian W. А.] Микаелян В. А., И. К. Айвазовский и его соотечественники,

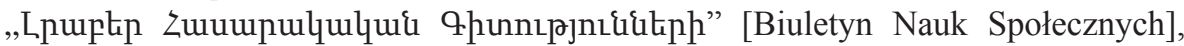
1991, 1, s. 69-70

[Mikaelian W. A.] Микаелян В. А., На Крымской земле. История армянских поселений в Крыму, Ереван 1974

Miławicki M., „Dlaczegożbym tedy nie miat pisać o bazylianach?”. O. Sadoka Baracza OP zainteresowania historia zakonu św. Bazylego, w: Pro bibliothecarum et bibliothecariorum bono. Księga jubileuszowa z okazji 70. urodzin profesor Marii Pidtypczak-Majerowicz, red. J. Czyrek, B. Górna, Wrocław 2016, seria: Z problemów bibliotek naukowych Wroctawia, 12, s. 195-213

Miławicki M., „Świat ode mnie zawsze rzeczy nadzwyczajnych wymagat, a ponadto niestusznie”. O. Sadok Wincenty Barącz OP (1814-1892) w świetle źródet, „Lehahayer”, 2, 2013, s. 153-198

Miławicki M., ,Zostaję raz na zawsze życzliwym przyjacielem”. Korespondencja pomiędzy historykami Augustem Bielowskim i dominikaninem Sadokiem Baraczem, „Galicja. Studia i Materiały", 3, 2017, s. 277-349

[Mocowkina O. W.] Моцовкіна О. В., Развитие конфессиональных учебных заведений Крыма в XX - первой половине XX века, Ялта 2011 (rozprawa doktorska http:// dspace.pdpu.edu.ua/handle/123456789/1133)

Mouradian C., La vitalité d'une presse en diaspora, w: Presse et mémoire. France des étrangers, France des libertés, Paris 1990, s. 35-45

Mouradian C., Kunth A., Les Arméniens en France. Du chaos à la reconnaissance, Toulouse 2010

[Polin S. W.] Полин C. В., Алексеев А. Ю., Скифский цзарский Александропольский курган IV в. до н.э. в Нижнем Поднепровье, Киев-Берлин 2018, seria: Кургань Украиньл, 6

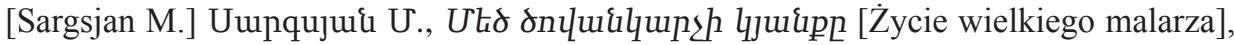
Epluuq [Erywań] 1990 (wersja rosyjska: Саргсян М. С., Жизнь великого мариниста: Иван Константинович Айвазовский, tłum. Е. Барашьян, Феодосия-Москва 2010, seria: Портрет мастера, 3)

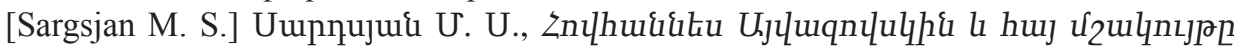
[Howhannes Ajwazowski i kultura ormiańska], „Tuunưu-puiduuppulquid huuntuu" [Czasopismo Historyczno-Filologiczne], 1963, 4, s. 25-38

Sargsjan T., Minas Bżyszkian i jego relacja o Ormianach Lwowa, „Lehahayer”, 5, 2019, S. 159-193, https://doi.org/10.12797/LH.05.2018.05.07

[Semenow I. Ја.] Семенов И. Я., Русские в истории Армении, red. М.Д. Амирханян, Ереван 2009

[Skorobogaczewa] Скоробогачева Е. А., Айвазовский, Москва 2021

Szafrański A., Ajwazowski Gabriel, w: Encyklopedia katolicka, 1, Lublin 1973, kol. 206

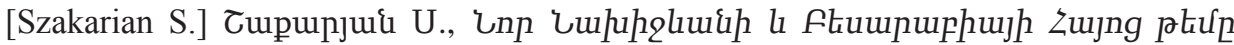
[Dziecezja ormiańska Nowego Nachiczewanu i Bessarabii], Łqưułdh\{ [Eczmiadzyn] 2014

Szmurło Z. T., Gabriel Ajwazowski - duchowny, uczony i pedagog, „Kognitywistyka i Media w Edukacji”, 2013, 2, s. 156-185

[Szuszara T.] Шушара Т., Развитие образования армян в Крыму XIX - начала XX века, „Гуманитарные науки”, 2015, 3(31), s. 76-79 
[Szuszara T.] Шушара T., Становление и развитие образования армян в таврической губернии в XIX - начале $X X$ в., „Fuiptp Epluwip hưuquupuih, Zujuuqhunnıp]nı\{" [Biuletyn Uniwersytetu Erywańskiego], seria: Zujuquhunnıpjnı\& [Armenistyka], 132, 2010, 1, s. 74-77

Şişman A., Egyptian and Armanian Schools Attended by Ottoman Students in Paris, „Uşak Üniversitesi Sosyal Bilimler Dergisi”, 2, 2009, 1, s. 1-10, https://doi.org/10.12780/ UUSBD37

Ter-Minassian A., Ä̈vazovski (1817-1900) un peintre Armenien dans le grand siecle Russe, „Fuquuultuw / Bazmavep”, 167, 2009, s. 486-515

[Ter-Sarkisjanc A,] Тер-Саркисянц А., Из истории формирования армянской диаспоры в России (X-XX в8), „Iran and the Caucasus”, 3/4, 1999/2000, s. 325-336

[Ter-Sarkisjanc A. Je.] Тер-Саркисянц А. Е., Культурное наследие армян в Крыму, w: Армяне Юга России: история, культура, общее будущее: материаль III Международной научной конференичии (2. Ростов-на-Дону, 30-31 мая 2018 г.), red. Г. Г. Матишов, Ростов-на-Дону 2018, s. 193-197

[Timigrazin A. D.] Тимиргазин А. Д., Член армяно-католической Конгрегации Мхитаристов на острове Св. Лазаря в Венеции Минас Бжикяни (Минас Медици), „Исследования по арменистике в Украине”, 1, 2008, s. 112-116

Tournebize F., Ä̈vazovsguy ou Ä̈vazovski (Gabriel), w: Dictionnaire d'histoire et de géographie ecclésiastiques, 1, red. A. Baudrillart et al., Paris 1912, s. 1234-1235

[Tunjan W. G.] Тунян В. Г., „Положение” Армянской изеркви 1836-1875, Ереван 2001

[Wagner Ł. A.] Вагнер Л. А., Григорович Н.С., Айвазовский, Москва 1970.

[Wartanian W. G.] Вартанян В. Г., Архиепископ Г. Айвазовский и основание Халибовского училищза в Феодосии, w: Армяне юга россии: История, культура, общее будущее. Материаль всероссийской научной конференции 30 мая - 2 июня 2012 г. Ростов-на-Дону, Ростов-на-Дону 2012, s. 334-340

[Wartanian W. G.] Вартанян В. Г., Казаров С. С., История Армянской Апостольской церкви на Дону (ХVIII-XX в.в.), Ростов-на-Дону 2004

Wasyl F., Ormianie $w$ świetle zapowiedzi przedmatżeńskich rodzimej parafii $w \mathrm{Ku}$ tach, „Krakowskie Pismo Kresowe”, 8, 2016, s. 93-267, https://doi.org/10.12797/ KPK.08.2016.08.04

[Wołobujew O. W.] Волобуев О. В., Армяне в Крыму: основные вехи истории, w: Армяне в истории и культуре России ХVIII-ХХ вв.: материаль международной научной конференции (Москва-Пушкино, 26-28 октября 2016 г.), red. П. М. Петров, Т. И. Любина, Ростов-на-Дону 2016, s. 198-205

[Zacharowa Ju. W.] Захарова Ю. В., Религиозная и просветительская деятельность Габриэла (Гавриила) Константиновича Айвазовского, „Причерноморье. История, политика, культура", seria: Б, 1, 2009, s. 175-178

Zaleski T., Słownik biograficzny duchownych ormiańskokatolickich oraz duchownych rzymskokatolickich pochodzenia ormiańskiego w Polsce $w$ latach 1750-2000, Kraków 2001

Zięba A. A., Idea powrotu Ormian z rozproszenia do narodowej ojczyzny w świetle memoriałów Roberta Bogdanowicza z 1877 i 1884 roku, „Lehahayer”, 7, 2020, s. 191231, https://doi.org/10.12797/LH.07.2020.07.04

Zięba A. A., Przemiany tożsamości narodowej Ormian $w$ dobie walk o niepodległość Polski, schyłek XVIII - początek XXI wieku, w: Polscy Ormianie w drodze do niepod- 
ległej Polski. Materiały z konferencji naukowej. Kraków, 9-10 października 2018 r., red. S. Dziedzic, J. Paluch, Kraków 2018, s. 13-36

\section{Netografia}

http://www.archiwum.ormianie.pl/archiwumk.php (Wirtualne Archiwum Polskich Ormian: indeks ksiąg metrykalnych parafii ormiańskokatolickich w Kutach, Czerniowcach, Horodence i Śniatyniu)

Marek Milawicki, OP, Minor contribution to the Armenian-Polish lineage of Aivazovsky family. A letter of the Archbishop Gabriel Aivazovsky to the Father Sadok Baracz from 1875

Abstract: In the correspondence of the Father Sadok Barącz OP, the historian of Polish Armenians, kept in the Library of the National Ossoliński Institute in Wrocław, there is a letter from the Armenian Archbishop Gabriel Aivazovsky, the brother of the painter Ivan. Robert Bogdanowicz, an Armenian landowner from Galicia, was the agent in contacts of these scholars. The letter relates to the family tradition of Aivazovskys concerning their origin from the community of Polish Armenians from the town of Stanisławów. Although the letter was already used in source literature, it has never been completely analysed. The article presents a letter edition in the original French language and translation into the Polish language, as well as an attempt of the letter data verification based on certificates of Armenian and Catholic parishes in Galicia against the biography of the author of the letter.

Keywords: Gabriel Aivazovsky, Ivan Aivazovsky, Sadok Barącz, Polish Armenians, Russian Armenians, Mechitarists, Galicia, Russia, Armenian Church, 19th century

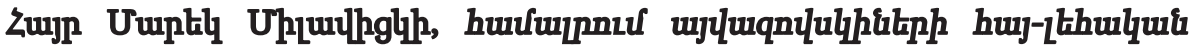

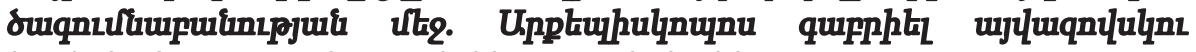

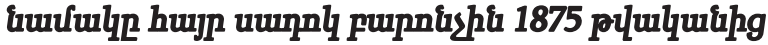

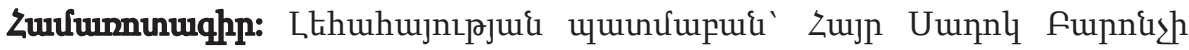

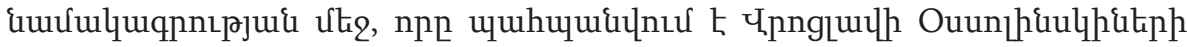

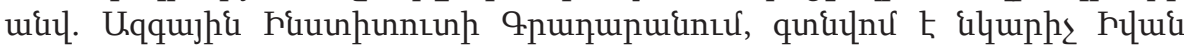

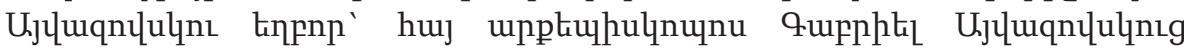

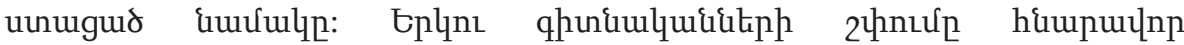

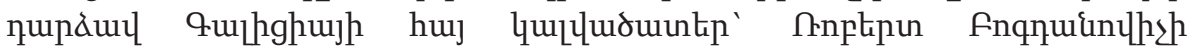

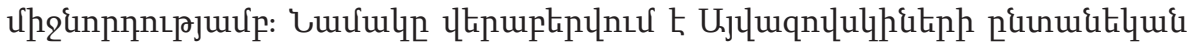

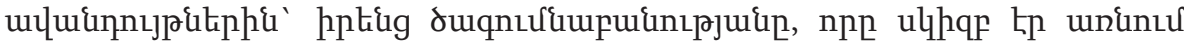

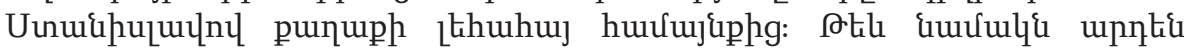

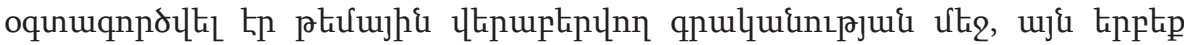

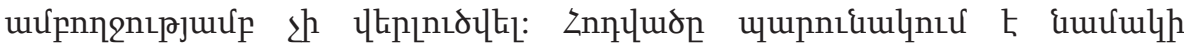

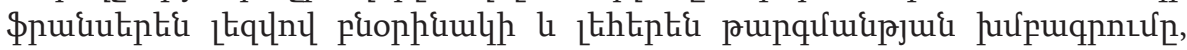




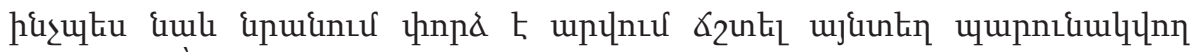

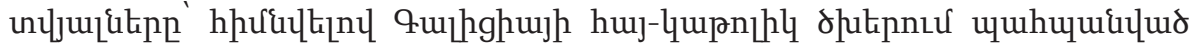

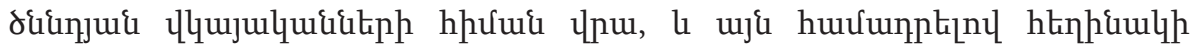
qtiuuuqnnıpuid htin:

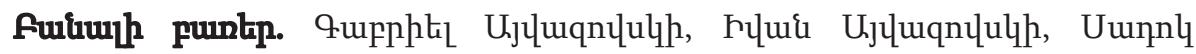

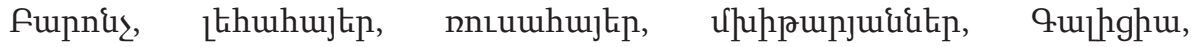

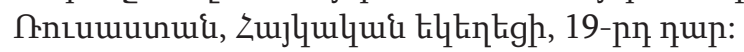




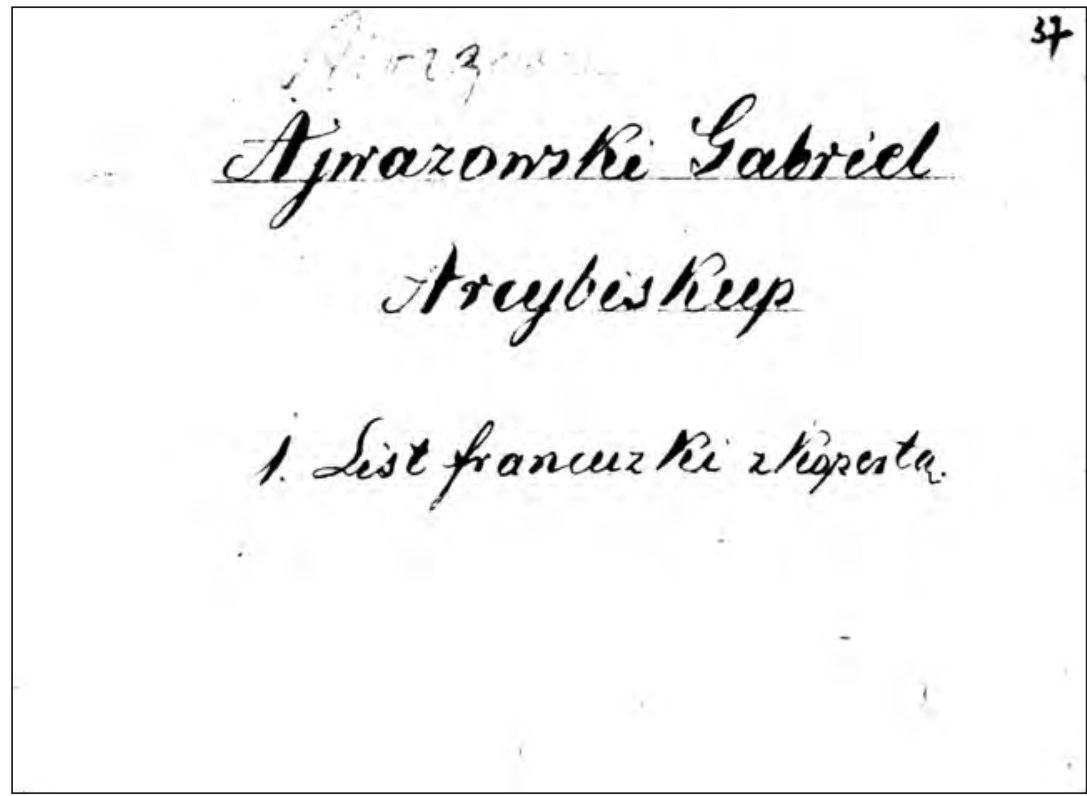

List arcybiskupa Gabriela Ajwazowskiego do ojca Sadoka Barącza, zbiory Biblioteki Zakładu Narodowego im. Ossolińskich, sygn 2756/I, s. 39-41 
39

illom Reverind bers.

Gres cher frewe in giseer Chent'

Si je prenis la liberte de vou importumes par

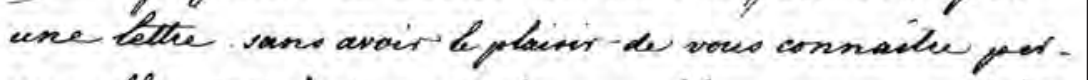
connellement, c'ert par wite des éloges que me fait constamment de votew binte at de vor bavaux, notu ame commun Al' le Ches: Robert de kotho. Bogdanovitch. - Jemetrourais encore a law, It a 18 ane, busqu jain sece de bie un exemplaire de

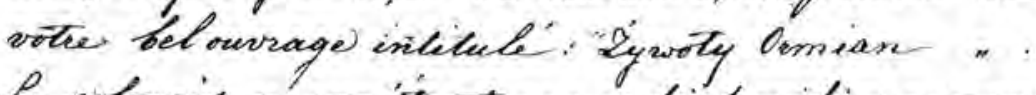
Sppolmais ne métant pas aufin famstier que quelques autes langues anciennes at moternes, jai er Dáboid ofeer dedifficulté pour bien comprendur et a.

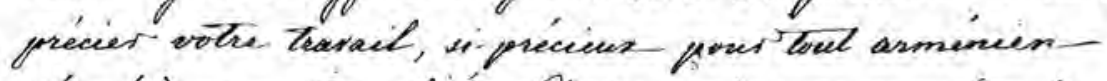
deveré à carnateonalite. Sardent divir de connaite à

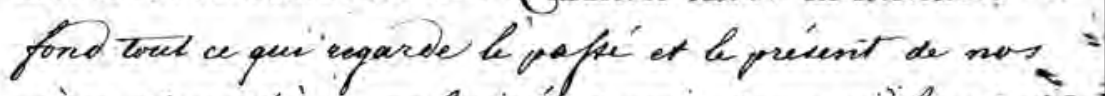
pires et confieres pronisés depoir deup sierles ot dima,

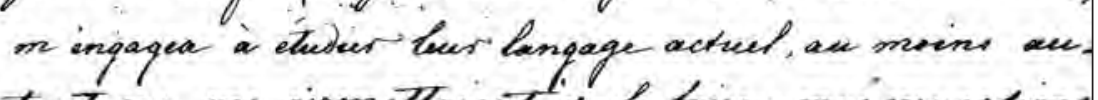
tant que me pirmettaient de le faire mes eccupations

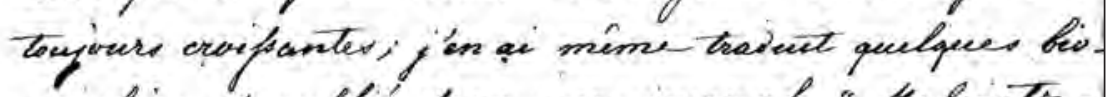
grophies it publie' dans mon journal "HafreatyAghawn "(2aclombe 2' Prarat), que je tie: geait mensueltement in arménien et en francaid. 


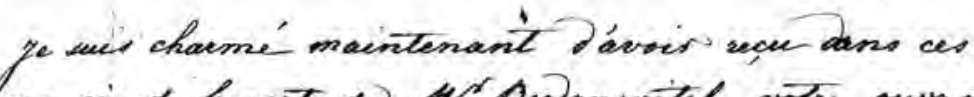

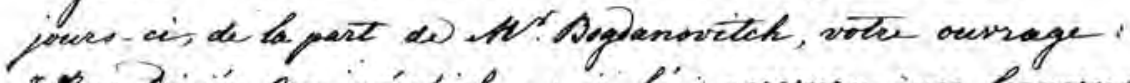

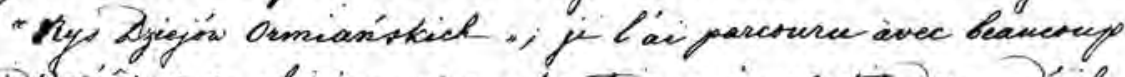

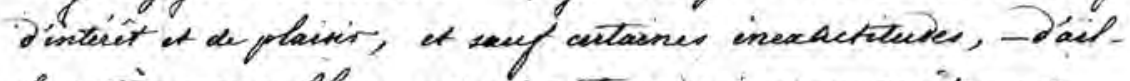

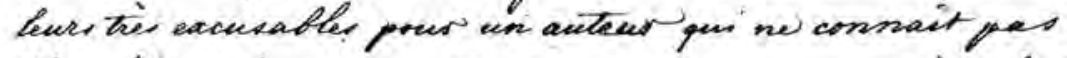

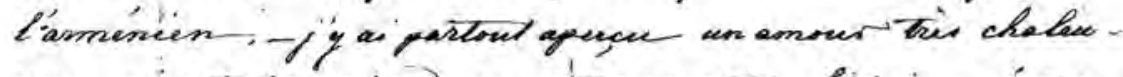

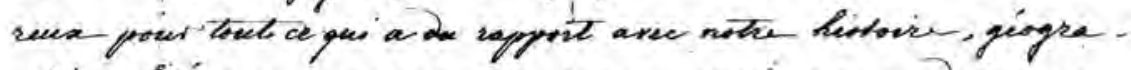

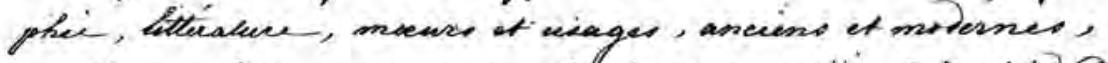

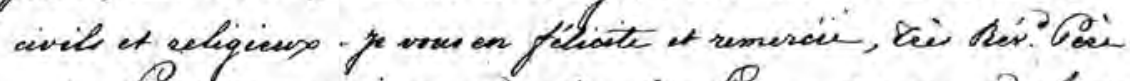

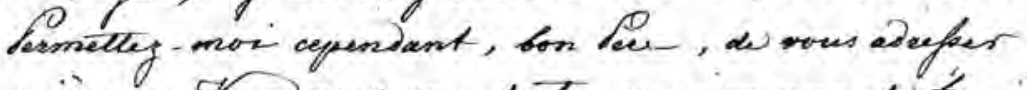

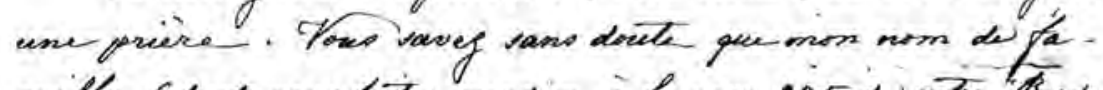

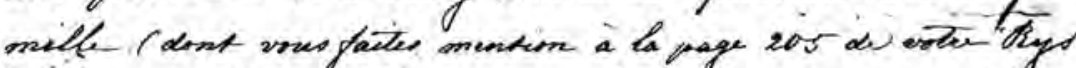

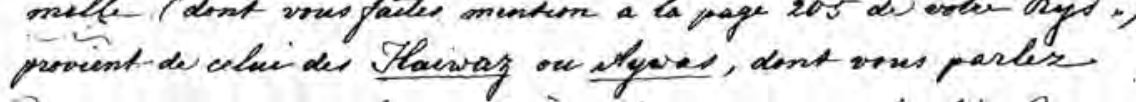

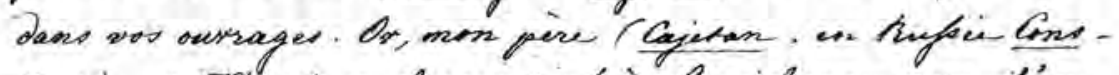

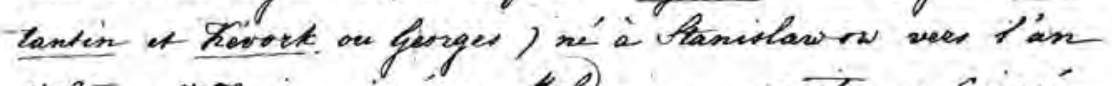

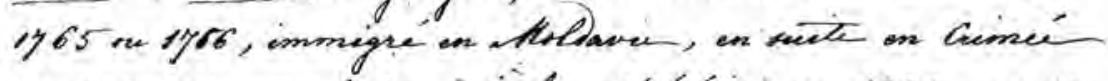

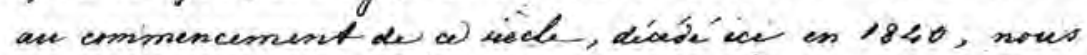

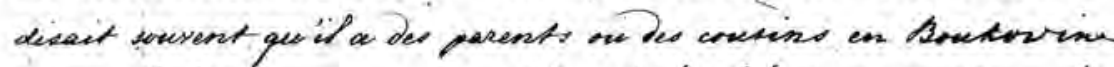

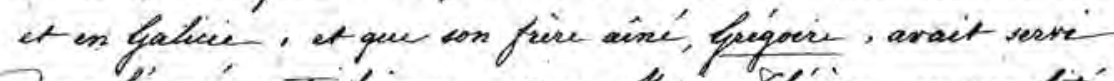

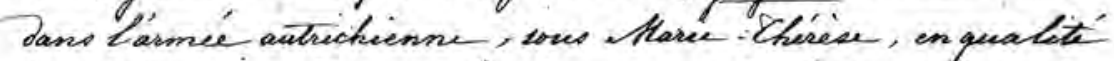
dechef de bataillon dis houpars, ene En pepant gar h

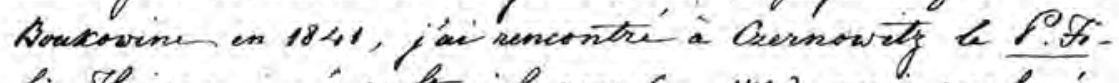

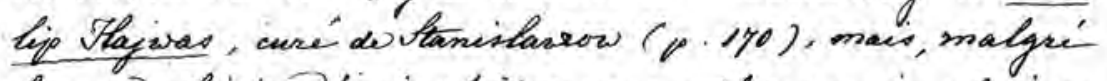

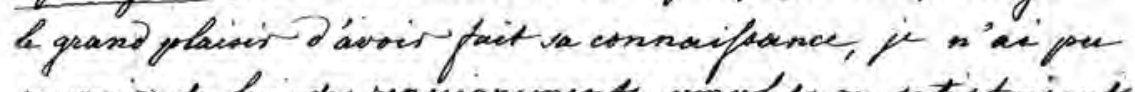

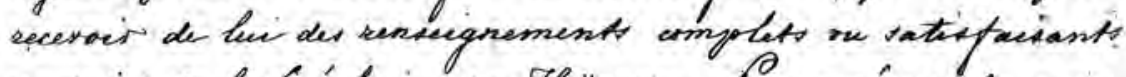

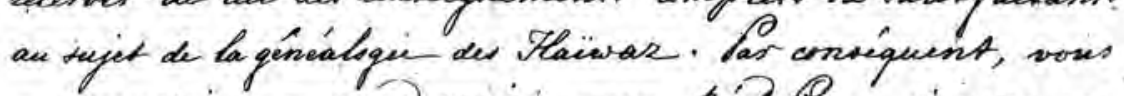

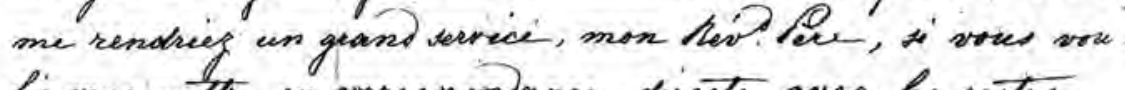

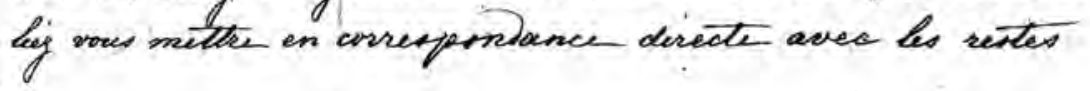


$4 i^{3}$

de cetle famille, biener de ar mefienes de notcer positives us lewer ancêtres, bur généalogi at lews testitions

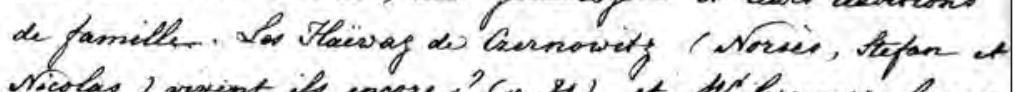

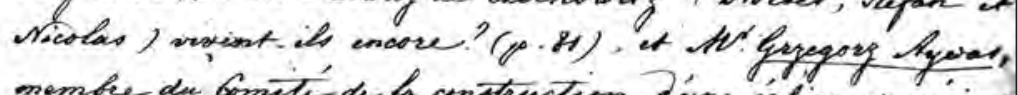

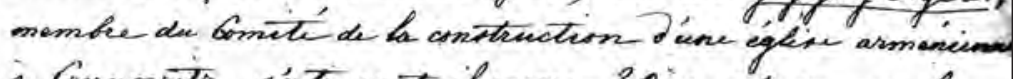
à Gernowity, s'y troure $t$-il encose Owenest-on area $b$

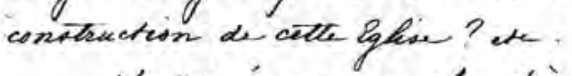

Y'owerpier, mon cher fiese on $Y . C$, que vous voudry bien me denner uneppermptè eiporses, et je vow prie sentiments fratanils avec liquel ir me exommande à eros prieker, et je medis.

Gies bividien,

Tote the humble servetur + Gabiel tivagovsty, archeréq.

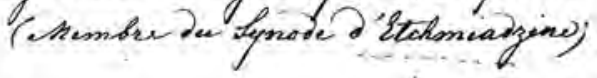

Ehiodovie (Kaffa) in Cimé. ce 25 yames (6 ferr.) 1875

Pf ye verais vans donte tai content is eres voulieg mécicire en francais, en ctalien me lation; mais je umporenss maintenant ofrey herlonais peres que voes preifeic entres likement wee mos en correvpon Pance dan cette langues 